\title{
IIII
}

UCLPRESS

Open Access

Megajournal project Town Hall

Twitter \#UCLOAMJ

(C) (i) Slides made available under
http://creativecommons.org/licenses/by/4.0/ https://doi.org/10.14324/111.1234

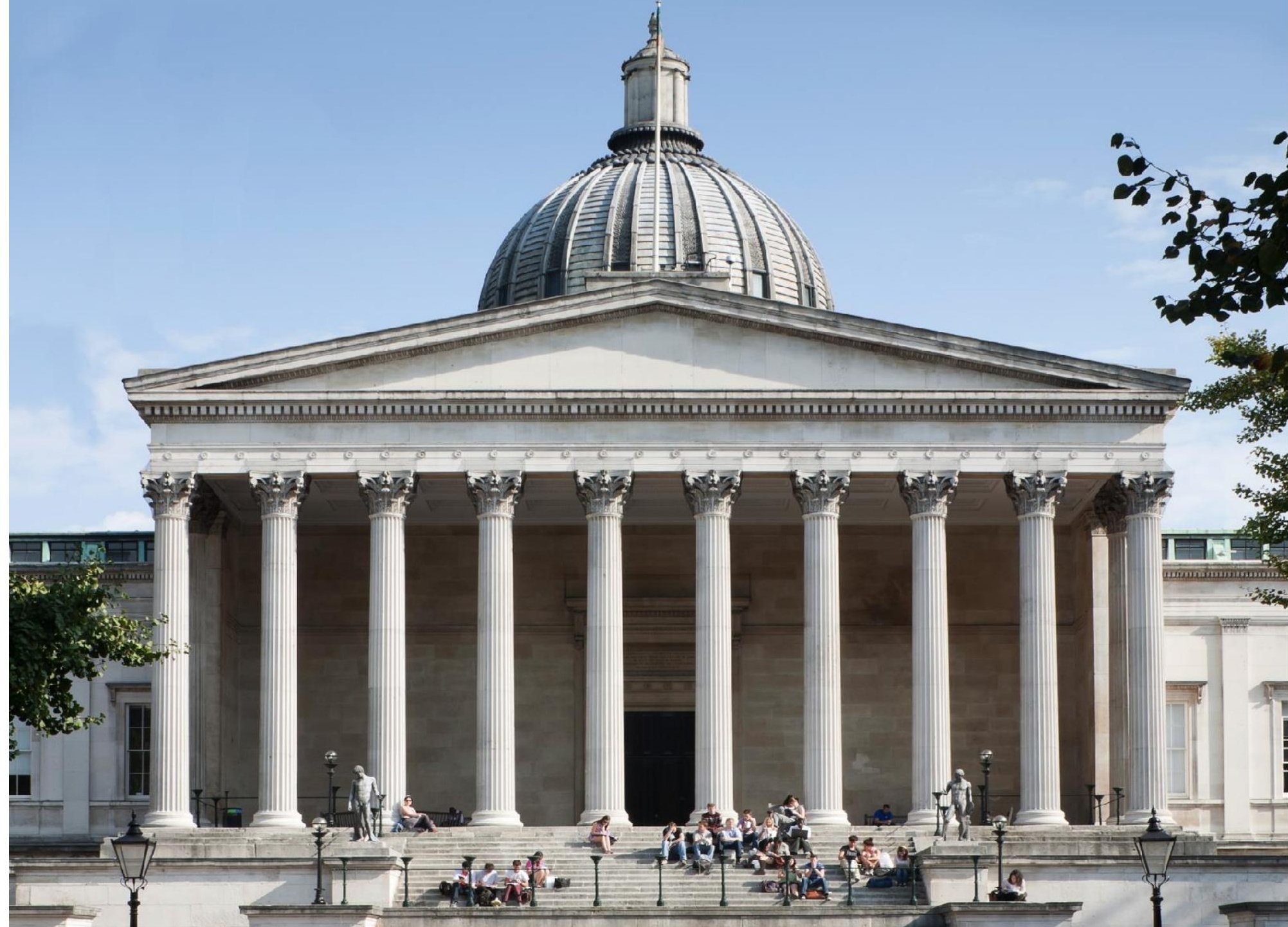




\section{Wellcome Open Research}

UCL mega journal launch $-16^{\text {th }}$ January 2017

\section{Robert Kiley, Wellcome Trust}

Head - Open Research (r.kiley@wellcome.ac.uk)

ORCID: 0000-0003-4733-2558

Twitter @robertkiley

(c) (i) Slides made available under http://creativecommons.org/licenses/by/4.0/ 


\section{Wellcome Open Research}

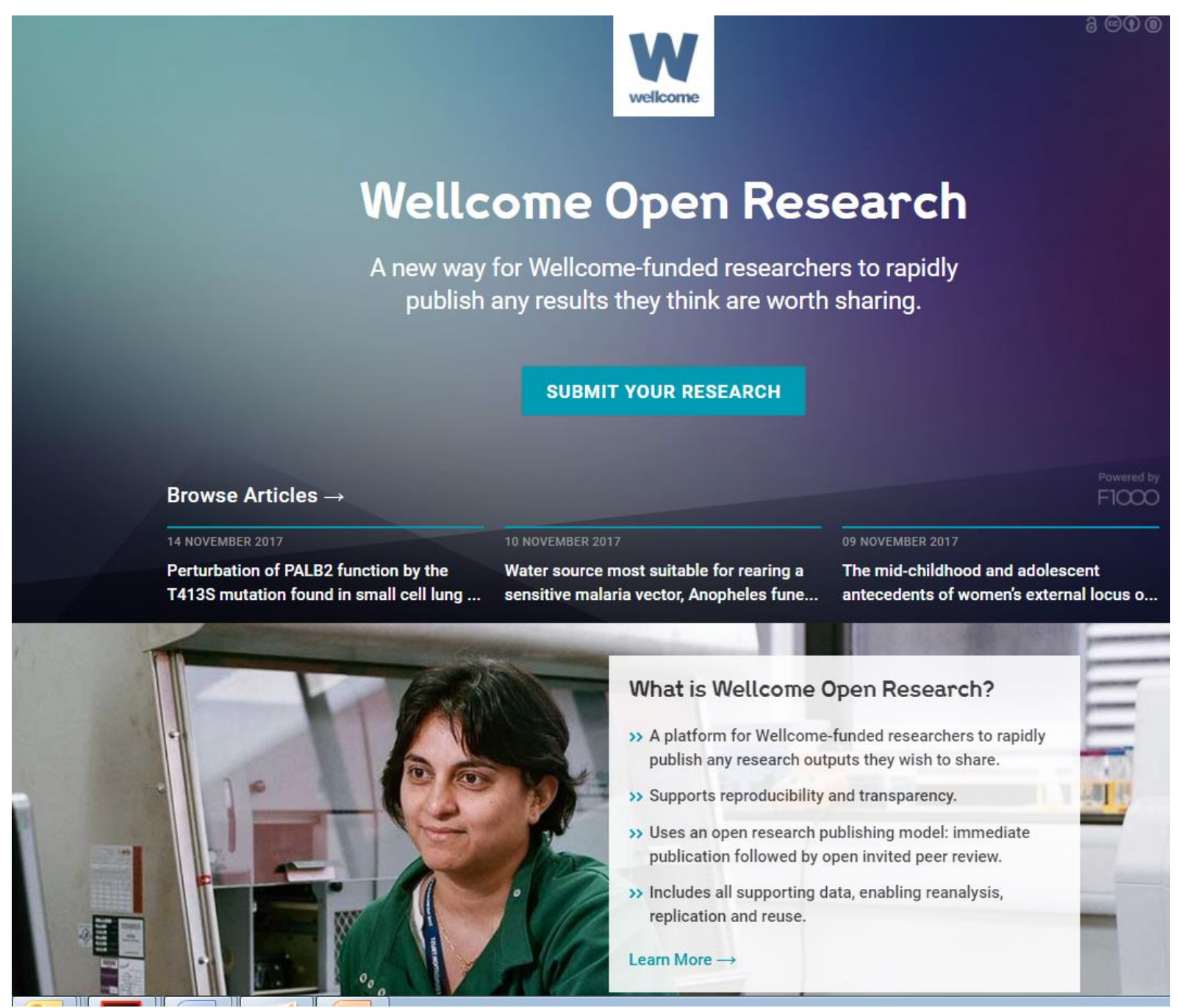

A new way for Wellcomefunded researchers to rapidly publish any results they think are worth sharing 


\section{Wellcome Open Research: making the sharing of results.....}

\section{- Faster}

- Transparent

- Reproducible

- Inclusive

- Cost-effective

\section{Speed}

\section{PublMed}

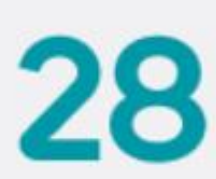

days $(n=142)$

Average time from Submission to Publication

\section{2 days $(n=100)$}

Average time from submission to being sent for indexing in PubMed 


\section{Wellcome Open Research: making the sharing of results....}

- Faster

- Transparent

- Reproducible

- Inclusive

- Cost-effective

\section{Open Peer Review}

Referee Status: $\checkmark \checkmark \checkmark \checkmark$

Invited Referees

\begin{tabular}{|c|c|c|c|}
\hline Version(s) & 1 & 2 & 3 \\
\hline REVISED & & $\checkmark$ & \\
\hline $\begin{array}{l}\text { Version 2 } \\
\text { published } \\
\text { 21 Jun } 2017\end{array}$ & & $\begin{array}{l}\text { read } \\
\text { report }\end{array}$ & \\
\hline $\begin{array}{l}\text { Version } 1 \\
\text { published } \\
18 \text { Nov } 2016\end{array}$ & $\underset{\text { read }}{\checkmark}$ & $\underset{\text { read }}{?}$ & $\checkmark$ \\
\hline
\end{tabular}

1 Yiannis loannou, Mount Sinai School of Medicine, USA

2 Andrew P. Lieberman, University of Michigan Medical School, USA

3 Maximiliano Gabriel Gutierrez, Francis Crick Institute, UK

4 Céline Cougoule, Institute of Pharmacology and Structural Biology (IPBS), France

Catherine Astarie-Dequeker, Centre National de la Recherche Scientifique, France

All reports (6), Responses and comments (4)

\section{Open Peer Review}

Referee Status: $\checkmark \checkmark \checkmark$

\begin{tabular}{lccc} 
& \multicolumn{3}{c}{ Invited Referees } \\
Version(s) & $\mathbf{1}$ & $\mathbf{3}$ \\
\hline Version 1 & & & \\
published \\
22 Jun 2017
\end{tabular}

Michael Metzger (iD, Columbia University, USA

2 Nicolas Bierne (iD), Institute of Evolutionary

Science of Montpellier (ISEM), France

3 Beata Ujvari (D), Deakin University, Australia

All reports (3)

Comments on this article

All comments (0)

Add a Comment

\section{Open Peer Review}

Referee Status: $\mathrm{X} X$

\begin{tabular}{lcc} 
& \multicolumn{2}{c}{ Invited Referees } \\
Version(s) & $\mathbf{1}$ & $\mathbf{2}$ \\
\hline Version 1 & $\mathbf{X}$ & $\mathbf{X}$ \\
published & read report & read report \\
24 2017 & &
\end{tabular}

1 Charles Affourtit, Plymouth University, UK

2 Philip Newsholme, Curtin University, Australia

All reports (2)

\section{Comments on this article}

All comments (0)

Add a Comment 


\section{Wellcome Open Research: making the sharing of results....}

- Faster

- Transparent

- Reproducible

- Inclusive

- Cost-effective

\section{Data availability}

Dataset 1 Zenodo: $10.5281 /$ zenodo. $163506^{18}$

Dataset 2 Zenodo: 10.5281/zenodo. $268899^{19}$

The cumulative list of all scored phenotypes analysed in this study is presented in Dataset 1 (homozygous mutants) and Dataset 2 (wild type embryos). The intermediate and high level slims of the MP ontology used in the analysis are presented in Supplementary table 2 and Supplementary Table 3. All data used in this study is also available from the DMDD web site (https://dmdd.org.uk) where phenotype annotations are available in tabular format by embryo and by line. In addition, they are identified at their appropriate locations within each 3D dataset of embryo images, which can be viewed in all three orthogonal section planes.

\section{Data \& Software}
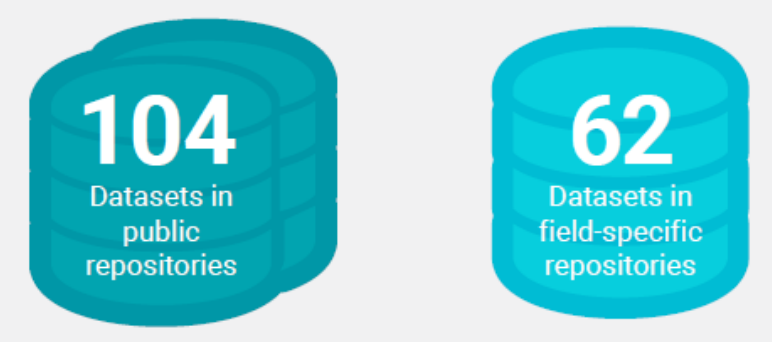


\section{Wellcome Open Research: making the sharing of results.....}

- Faster

- Transparent

- Reproducible

- Inclusive

- Cost-effective

\section{$60 \%$}

Traditional research articles

Top 5 article types
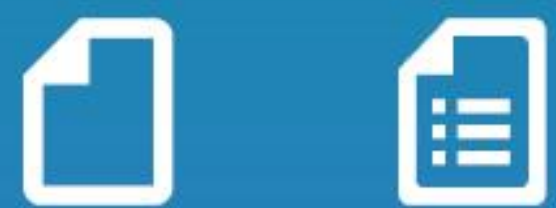

Research article

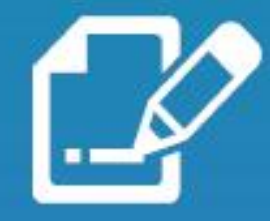

Research note
$40 \%$

Other article types

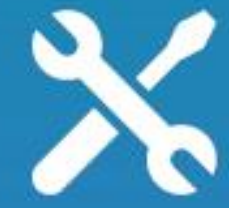

Software tool 


\section{Wellcome Open Research: making the sharing of results....}

- Faster

- Transparent

- Reproducible

- Inclusive

- Cost-effective

\section{Article Processing Charges}

All content published on Wellcome Open Research is fully Open Access immediately on publication. The publication costs are covered through article processing charges, which are funded centrally by Wellcome. This means that researchers funded by Wellcome can publish on the platform without direct cost to them. Authors will only be asked to provide details of their Wellcome grant on submission.

Article processing charges levied by the service provider, F1000, are based on word counts (of the manuscript main body), irrespective of the article type. Wellcome is only charged a fee for submissions that pass the pre-publication checks and are published. Wellcome receives a 10\% discount on F1000's standard fees; this discount is included in the listed price:

\begin{tabular}{|l|r|}
\hline WORD COUNT & PRICE * \\
\hline up to 1000 words (short article) & $£ 116$ \\
\hline $1000-2500$ words (medium article) & $£ 387.50$ \\
\hline over 2500 words (long article) $\#$ & $£ 775$ \\
\hline
\end{tabular}




\section{Wellcome Open Research: a researcher- centríc way of publishing}

Researchers decide:

- What to share

- When to share

- Who is best placed to review it

- How to respond to reviewer comments

- When to update/revise an article

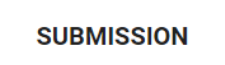

ก

Submit your article and data You suggest referees

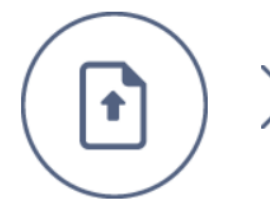

四

Pre-publication checks for adherence to policies +
typesetting: 7 days
PUBLICATION

R

Tell your colleagues your article

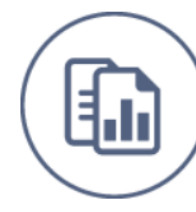

四

Publish article and source data; label 'awaiting peer review'
OPEN PEER REVIEW AND REVISION

○

Publish new article versions: linked and independently citable

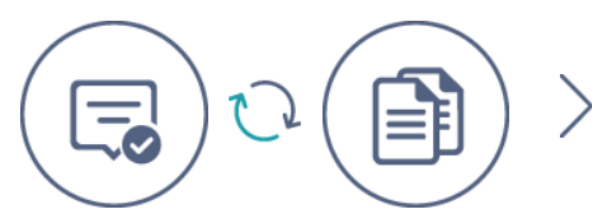

$$
\text { 四 }
$$
Check author-suggested expert referees
for suitability and ingite. Publish referee reports and names alongside article.
DISSEMINATION

ก

Pass peer review, get PubMed and increase visibility

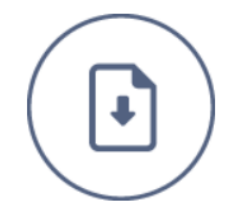

回 Index in bibliographic databases 


\section{Wellcome Open Research: Year 1}

- Published 142 articles; 100 of which indexed in PubMed

\section{A year of \\ Wellcome Open Research}

- Articles now indexed by Scopus

Authors

- 35 articles have at least one citation

- Most cited article is a data note (6 citations); most viewed article with over 3500 views is a method paper
1,012

Number of authors

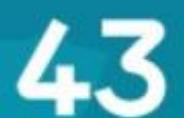

Number of countries represented

Articles

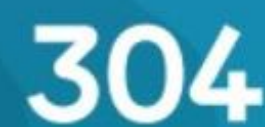

Number of institutions represented

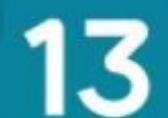

Number of Wellcome Centres and Institutes represented
142

Number of articles

100

Number of articles sent to PubMed 


\section{Rise of funder platforms....}

- Growing number of funder platforms - including Gates, Health Research Board, and others

- EC seeking to develop Open Research Europe

- Development of Open Research Central

- Currently an aggregation service

$Q$

\section{Open Research Central}

The central portal for open research publishing

IMMEDIATE PUBLICATION I OPEN DATA

OPEN PEER REVIEW I OPEN ACCESS

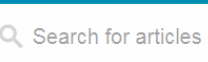

BROWSE ARTICLES

- In time, potentially a "funder agnostic" publishing platform

Gates Open Research

Immediate \&

Transparent

Publishing

Gates Open Research is a platform for

rapid author-led publication and open

peer review of research funded by the Bill

\& Melinda Gates Foundation

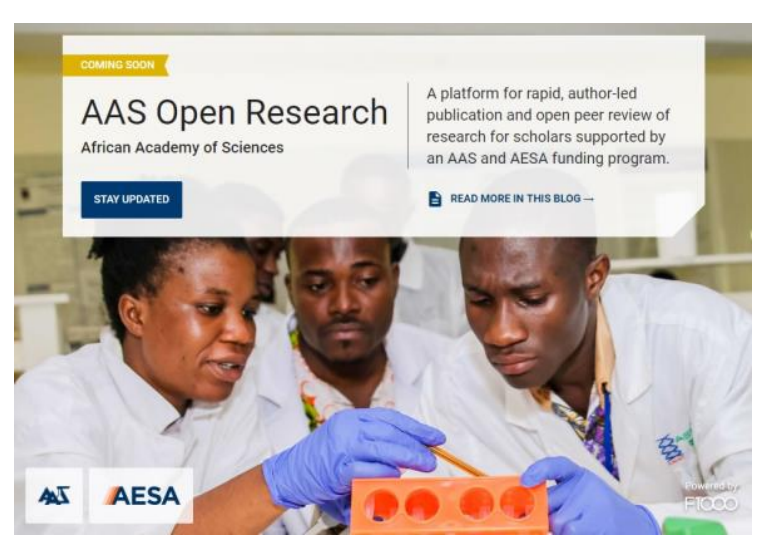

COMING SOON

HRB Open Research

A platform for HRB-funded researchers to publish their research outputs in an open and accessible way

STAY UPDATED

A READ MORE IN THIS BLOG $\rightarrow$ 
Questions?

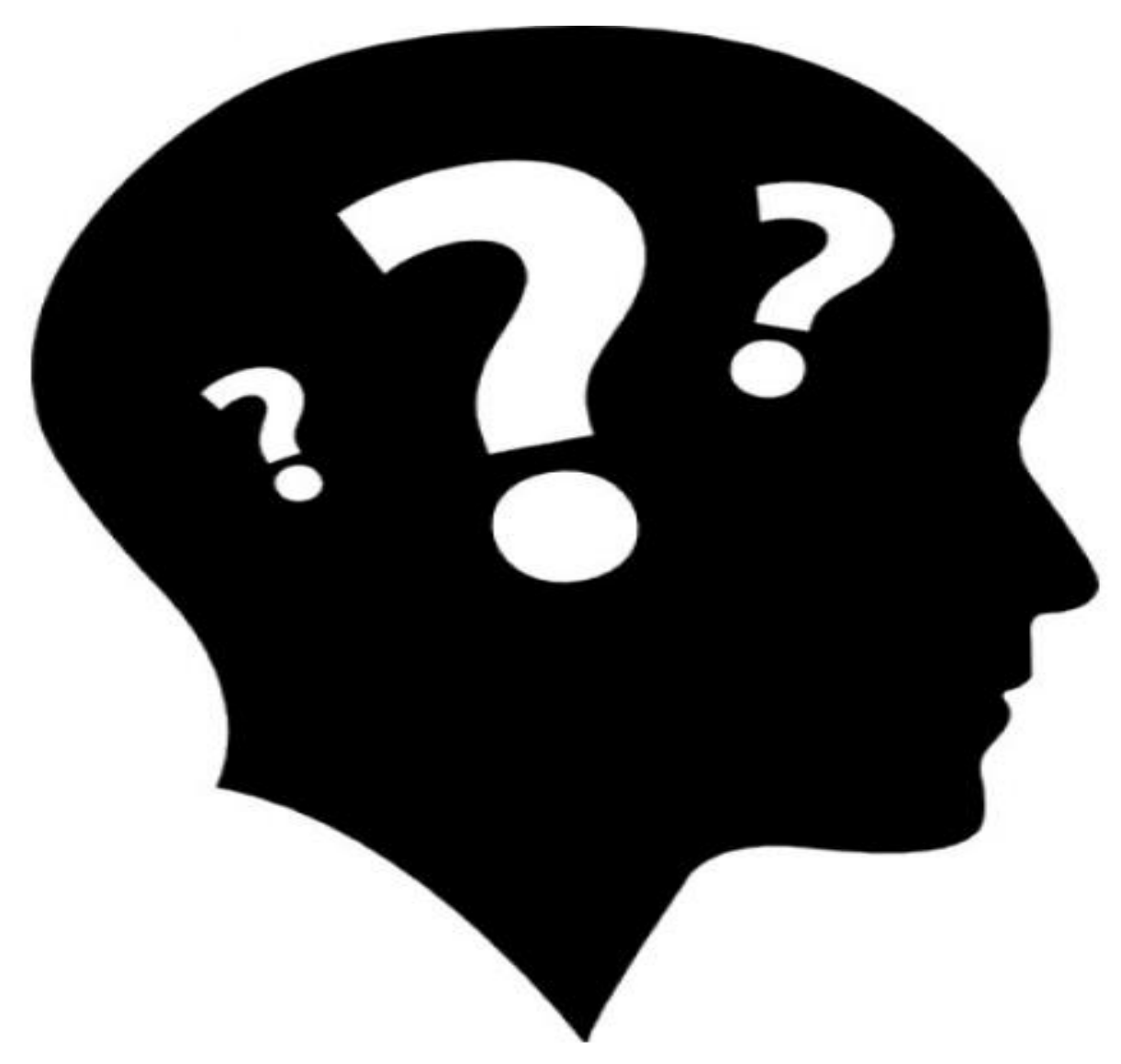




\section{ScienceOpen: Research in Context for UCL Press}

UCL Town Hall, London 16 January 2018 @Science_Open @SDawsonBerlin

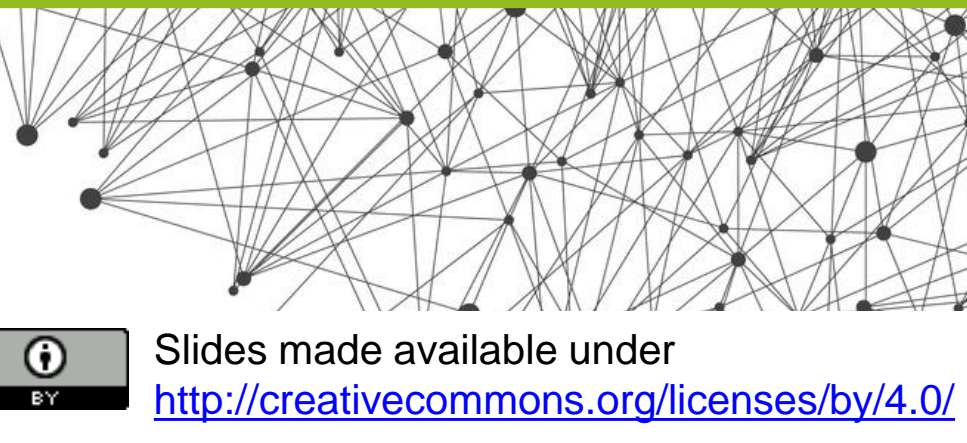

\section{http://creativecommons.org/licenses/by/4.0/}
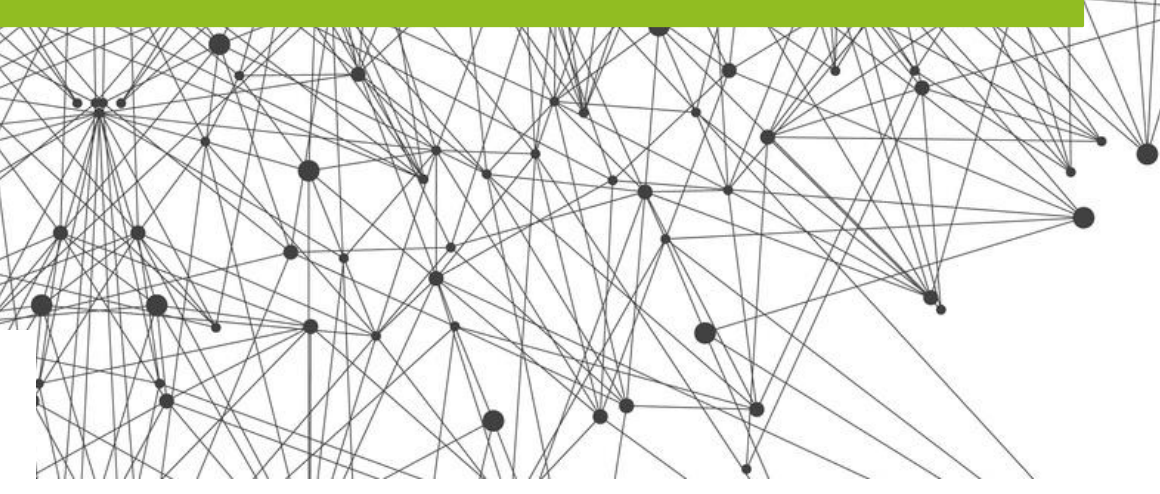


\section{Global search}

\section{enviornment}

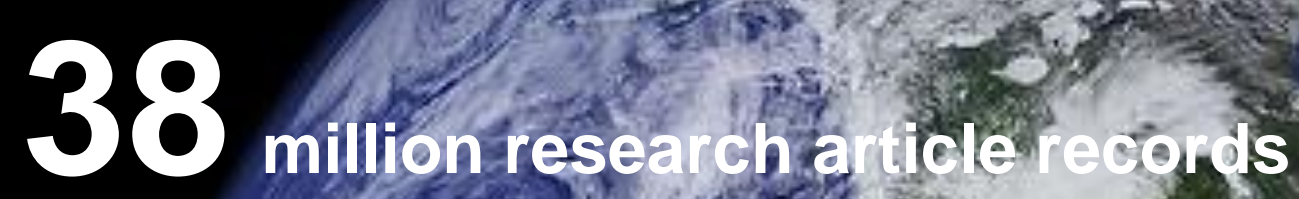

48 mint $x$ in

million avthors

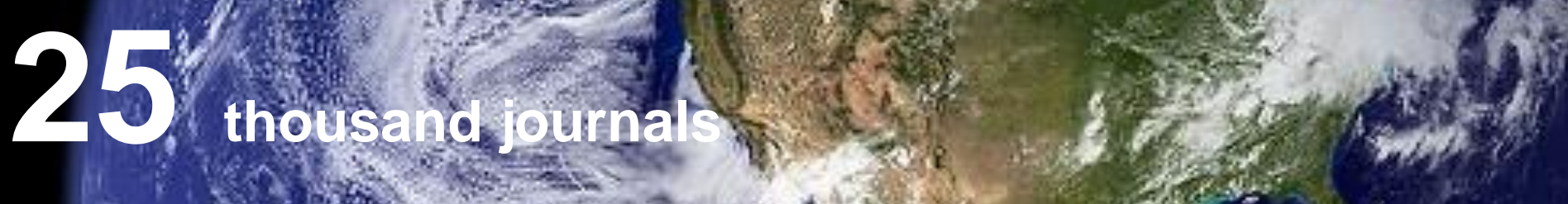

Re-Search starts here: Unlock the context around each article and reach a wider interdisciplinary academic universe with ScienceOpen. 
More than search: Context as a motor for discovery

author summary

similar articles

searchable reference lists

publisherSaved search

researcher curation

jouna citation discipine e citation kewword

vauthor

or preprint SOrtabstract

$$
\begin{aligned}
& \text { ORCID } \\
& \text { se filterdrill down } \\
& \text { so revisearch } \\
& \text { so open access profile } \\
& \text { featured collections }
\end{aligned}
$$

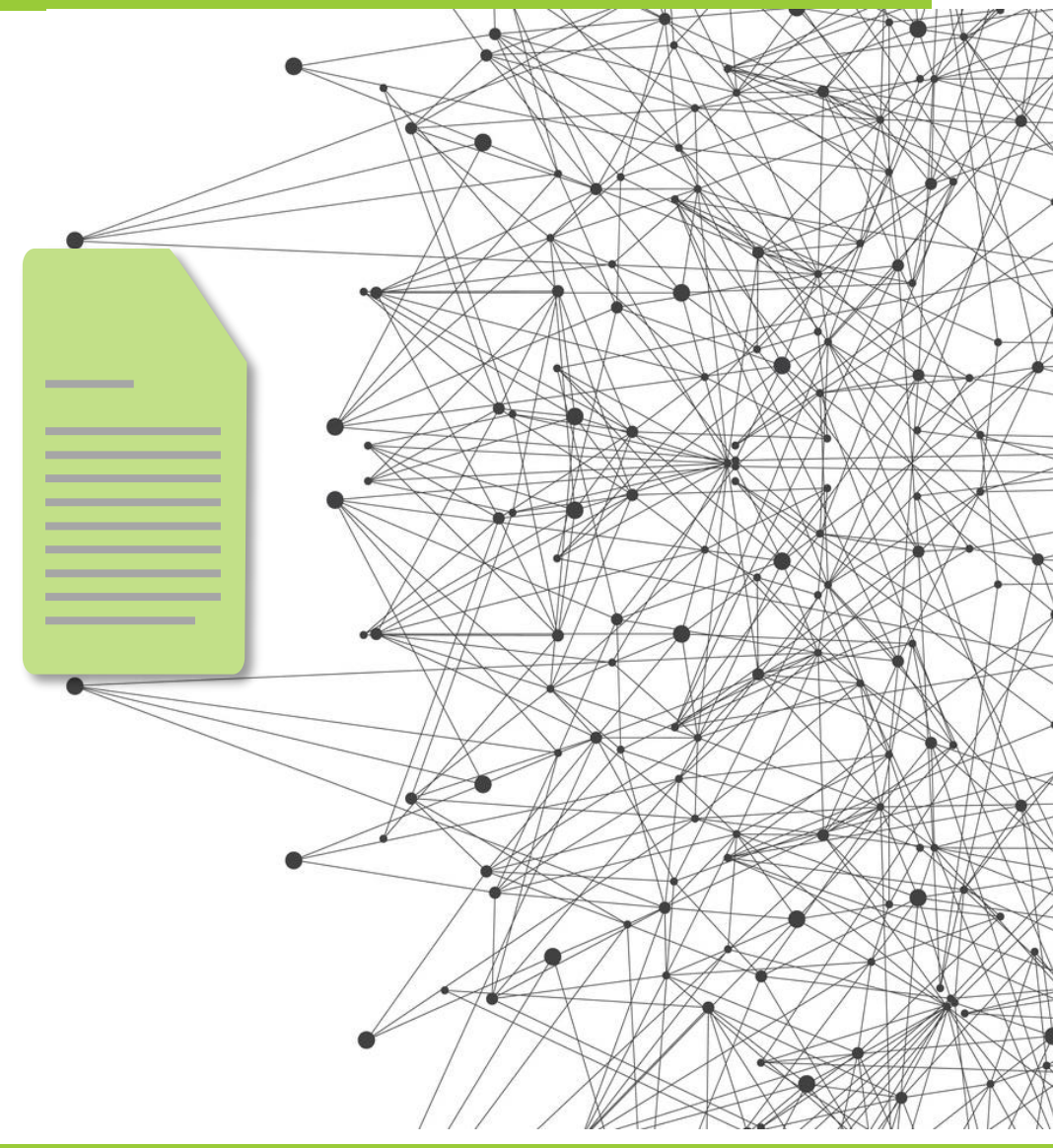




\section{The article: A hub of discovery and metrics}

\section{Article page:}

- Citations

- Comments

- Linked authors

- Related collections

- Similar articles

- Altmetric score

- Read button (link to article on publisher site)

ScienceOPEN.com

MY SCIENCEOPEN - BLOG ABOUT Q SEARCH +

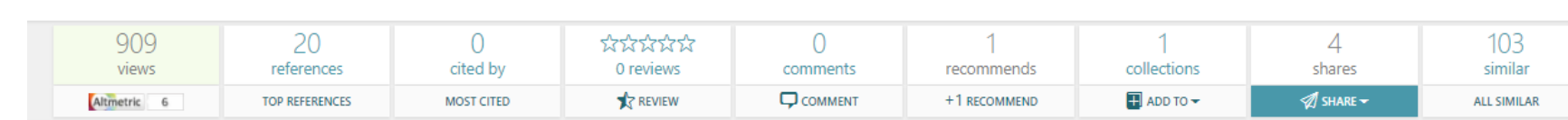

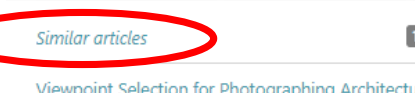

Viewpoint Selection for Photographing Architect
Authors: Iingwu He, LINBO WANG, Wenzhe Zhou

Computational Biology in Argentina Computational Biology in Argentina
Authors: Sebastian Bassi, Virginia Gonzzalez-Blanco, Gusta
Parisi

Proceedings of the 2008 MidSouth Computational Biology and Bioinformatics Society (MCBIOS)

Conference

(ics society (MCBIOS)



Most referenced authors

Ye Chen
103. RECORD ABSTIRACT ARTICE $\odot$

Computation and the Impact of New Technologies on the Photography of Architecture and Urbanism

Authors: Mitchell Schwarzer

Publication date ( Electronic ): April 2017

Journal: Architecture_MPs

Publisher: UCL Press

DOI: 10.14324/111.444.amps.2017y1114.001

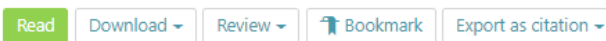

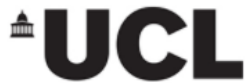
PRESS
39

There is no author summary for this article yet. Authors can add summaries to their articles on ScienceOpen to make them more accessible to a non-specialist audience.
Mitchell Schwarzer,

David Crandall.

Over the course of histony the meanings of buildings have repeatedly been expanded and altered via the creation of technologically driven information realms. In

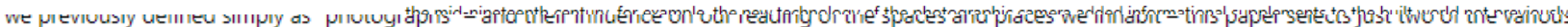
strands of this new phase of digital photographic imaging. It does so in the belief that these two particular, if unrelated phenomena, reveal their own particular insights into how the digital image may today, interact with our conceptualization of architectural forms and urban spaces.

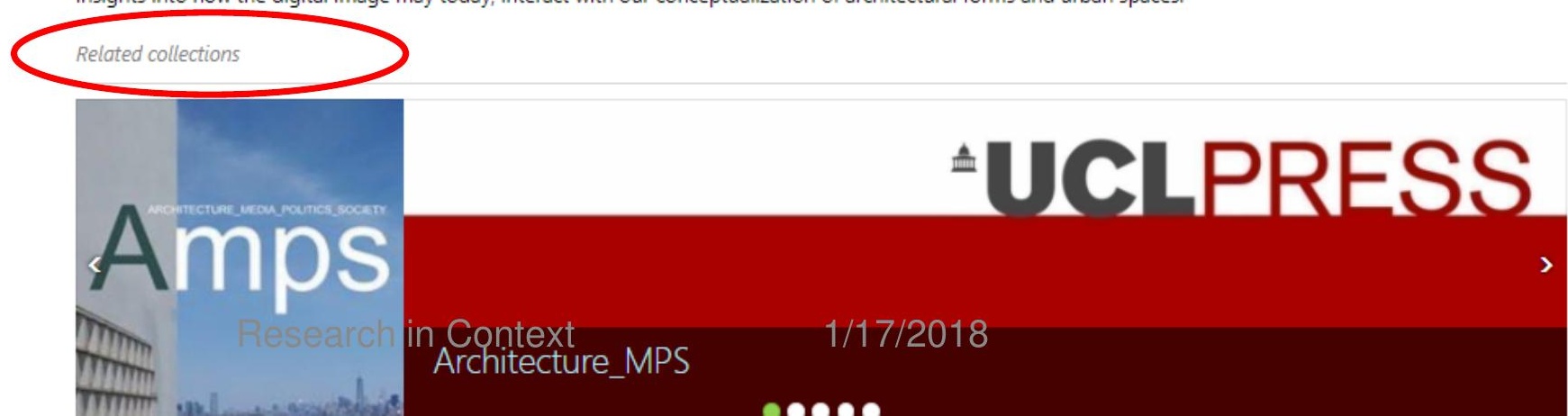




\section{ScienceOpen technical infrastructure underlying discovery environment}

\section{Metrics}

Usage dashboard Article metrics Journal statistics

\section{Discovery}

Similar articles

Collection banners

Lay summary

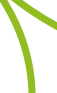

ray sun
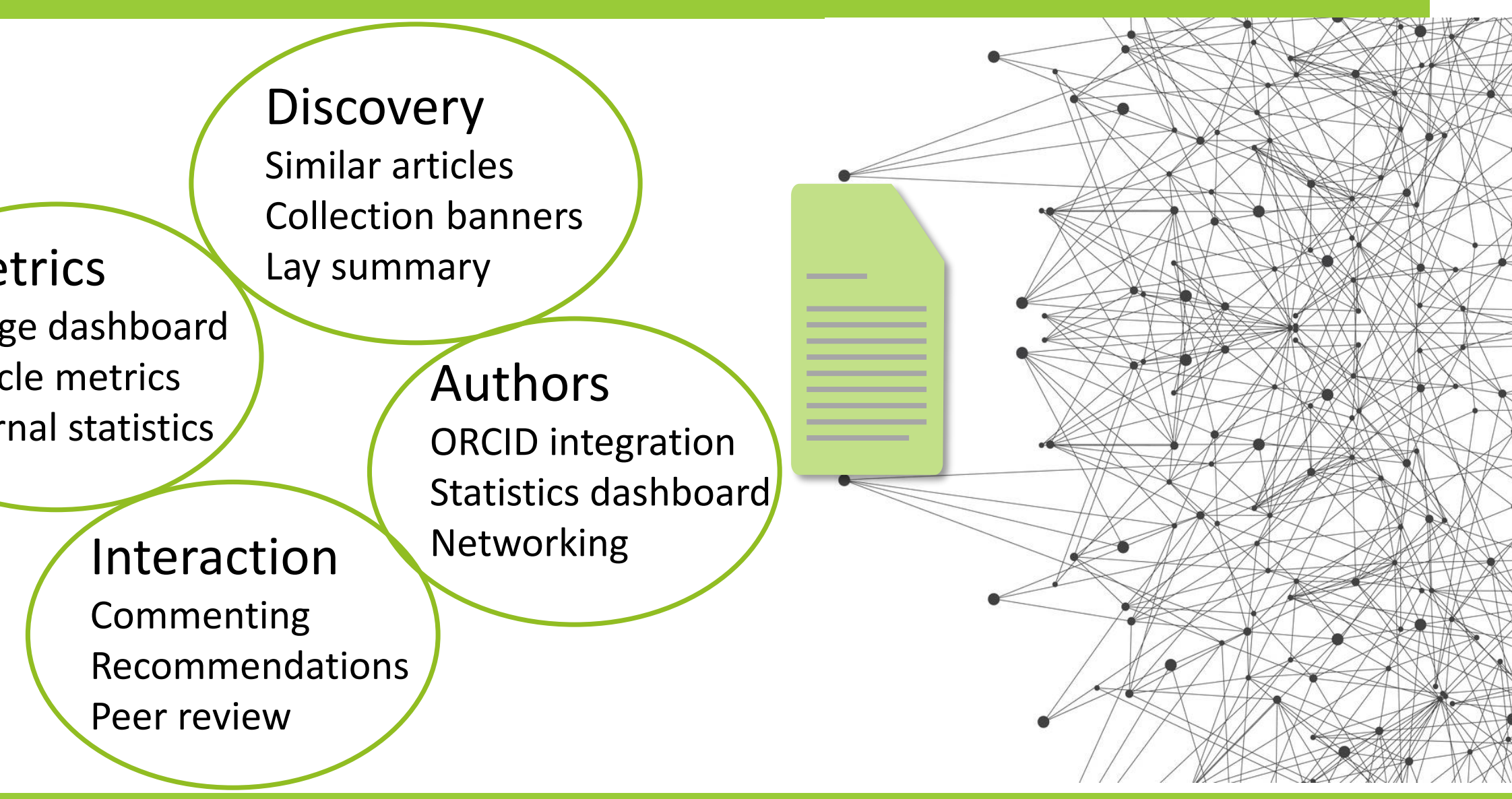
 \\ Beyond the journal webpage

\section{Publisher benefits from the} ScienceOpen discovery technology:

- Context:

Place your content in context of top articles in your field and beyond

- Insight: Understand how your content is used with ScienceOpen article and journal metrics

- Usage: Boost visibility with a link back to your version of record

- Community: Use ScienceOpen infrastructure to build communities around your journal

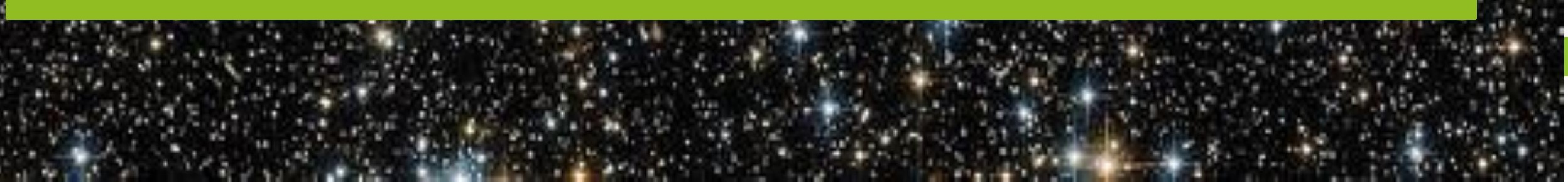




\section{Beyond the journal webpage}

\section{IUCLPRESS}

\section{Amps Thm \\ ITtmon

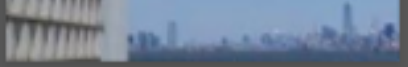

Architecture_MPS

A multi-disciplinary architecture open access journal by UCL Press publishing scholarly papers on the social and political interpretation of the built environment.

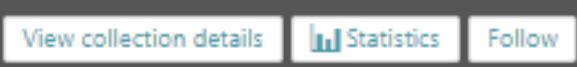

\begin{tabular}{c|c}
21 & 5.265 \\
21 & views \\
articles &
\end{tabular}

Narrow by publisher

UCL Press

21

Narrow by journal

Architecture_MPS

21

Narrow by discipline

\section{Publications}

Enter some words to filter items below

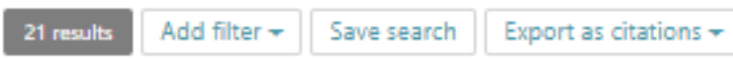

\section{RECORD}

Narratives of Urban Resistance: The Community Land Trust Udi Engelsman （2016)
22

recommends

onstitis 0 reviews
33

shares
4

followers
Sort by Altmetric score

Sort by average rating

Sort by cited by count

Sort by date

Sort by view count
New search $\mathrm{X}$ 


\section{Get found in dynamic search on ScienceOpen}

ScienceOPEN.com

research+publishing network

Narrow by collection

\begin{tabular}{l}
\hline International Journal of Social Pedagogy \\
\hline Patient Preference and Adherence \\
\hline Narrow by publisher \\
\hline UCL Press \\
\hline $\begin{array}{l}\text { Instituto de Investigación en Educación, } \\
\text { Universidad de Costa Rica }\end{array}$ \\
\hline Universidad de La Sabana \\
\hline Narrow by journal \\
\hline International Journal of Social Pedagogy \\
\hline International Journal of Educational Research \\
\hline Actualidades Investigativas en Educación \\
\hline Children Australia \\
\hline Educación y Educadores
\end{tabular}

\section{$\checkmark$}

Narrow by discipline

Education

Educational research \& Statistics

\section{Search}

New search $\mathbf{X}$

\begin{tabular}{|l|l|l|l|l|l|l|}
\hline Content & Authors & Collections & Featured & Journals & Publishers & \\
\hline social pedagogy & & & & \\
\hline 74 results & Add filter $~$ & Save search & Export as citations - & Sort by Altmetric score - V & Search Q \\
\hline
\end{tabular}

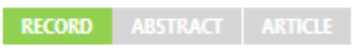

Toward a social pedagogy of classroom group work

Peter Blatchford, Ed Baines, Peter Kutnick, Maurice Galton (2003)

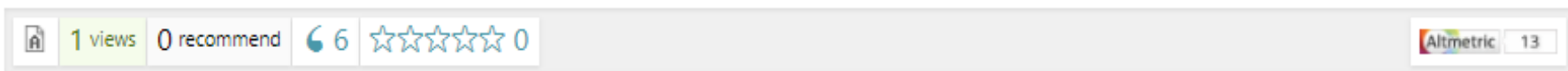

\section{RECORD ABSTRAC ARTICIE $ə$}

Educação social de rua: bases históricas, políticas e pedagógicas

Walter Oliveira (2007)

Aborda a educação social de rua como sistema pedagógico, surgido na América Latina ao final da década de 1970, quando chamava a atenção o crescimento das populações de rua, sobretudo crianças e adolescentes. Os primeiros educadores sociais de rua foram agentes de pastoral, na praça da S $\vee$ Show more

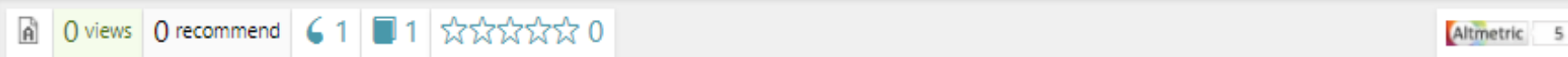




\section{A full suite of usage statistics on ScienceOpen}

\begin{tabular}{|c|c|c|c|c|c|c|}
\hline $\begin{array}{c}21 \\
\text { articles }\end{array}$ & $\begin{array}{l}5,265 \\
\text { views }\end{array}$ & $\begin{array}{c}56 \\
\text { altmetric }\end{array}$ & 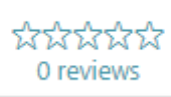 & 22 & $\begin{array}{c}33 \\
\text { shares }\end{array}$ & $\begin{array}{c}4 \\
\text { followers }\end{array}$ \\
\hline LATEST ARTICLES & MOST VIEWED & TOP ARTICLES & HIGHEST RATED & +1 RECOMMEND & \& SHARE - & Follow \\
\hline
\end{tabular}

Content in context

Collection's content in context

Publication statistics

Article count

Article view count

Average view count

Share count

Activity count (aggregated number of

recommendations, reviews and comments)
Article view count

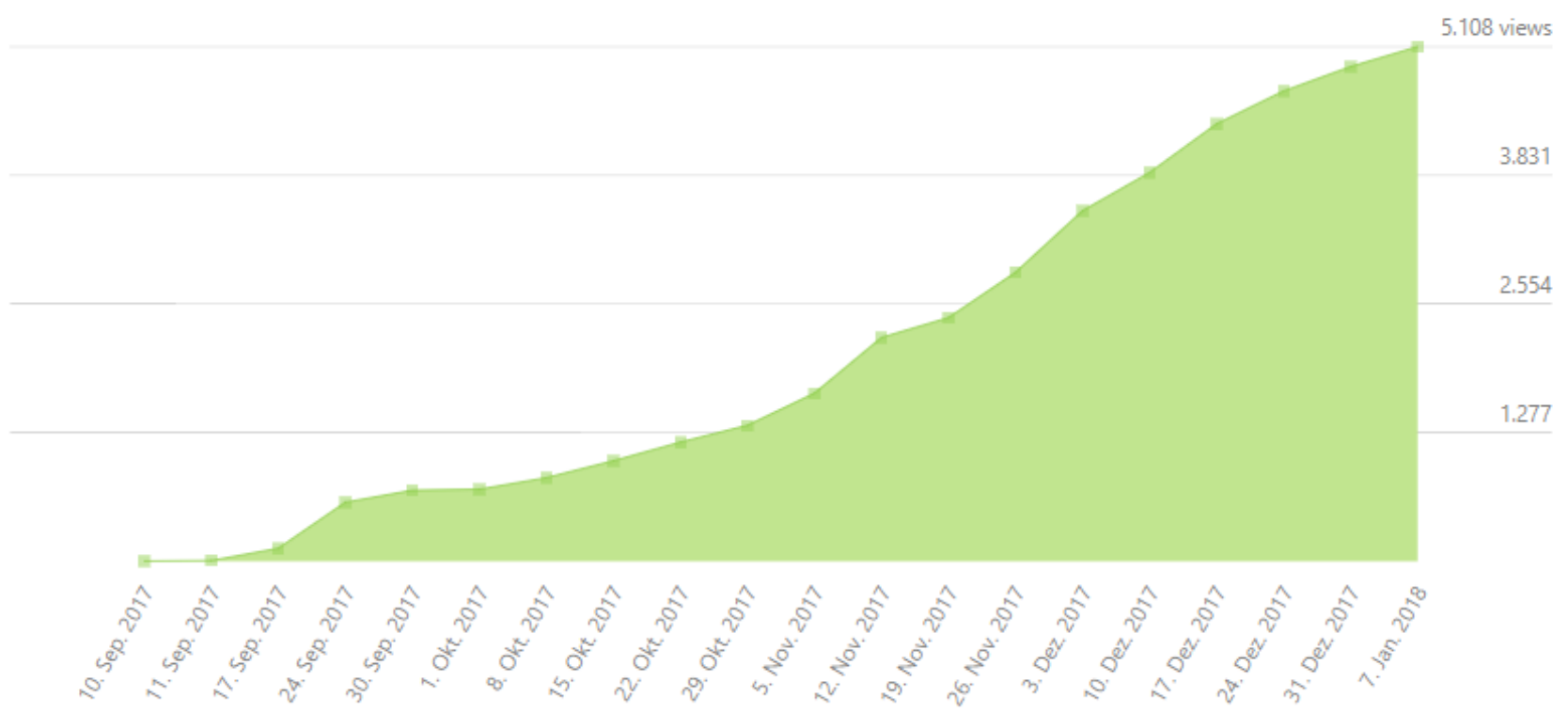




\section{Public Post-Publication Review}

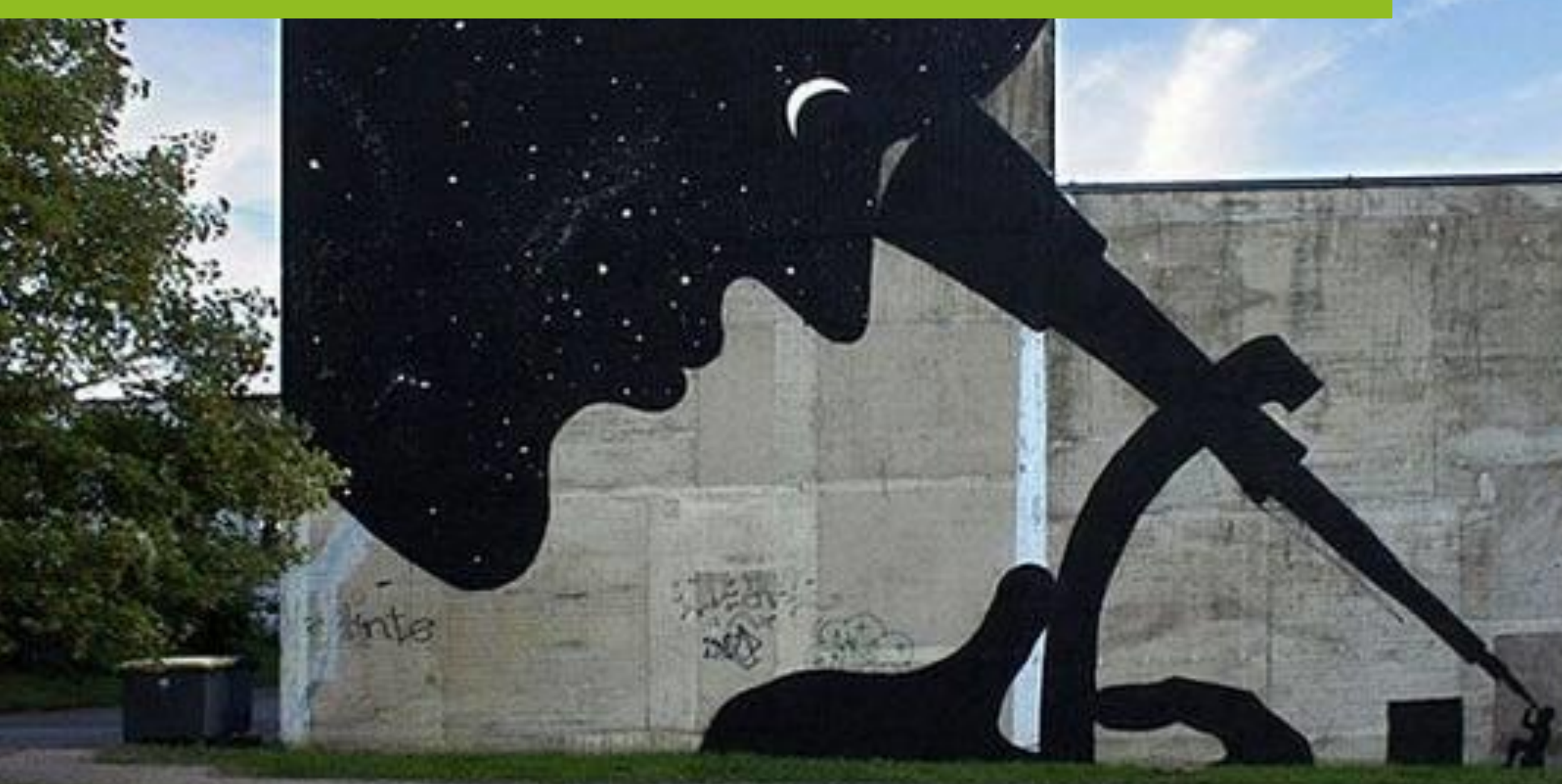

Street Artist SAM3 Image via http://photovide.com/street-art-murals-world/ 


\section{Open post-publication peer review mit ScienceOpen / Integration mit CrossRef, ORCID}

Review by Lauren Collister

$\widehat{\Lambda}$ Review

Lauren Collister evaluated the article as:

$\star \star \star \star \star ぇ$

What are the benefits and drawbacks of using a smartphone app to crowdsource language change data?

Publication date:

01 September 2016

DOI: $\quad$ 10.14293/S2199-1006.1.SOR-UNCAT A4699763.v1.RZVXZU

Level of importance: tht大th

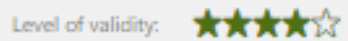

Leyel of completenes: ththts

Level of comprehensibility: tht大th

Competing interest: None

Recommend this review: $\quad+12$ people recammend this

\section{Comments}

This project is an interesting one and provides a step into the logical next step of studying language change. Using crowdsourcing via a mobile app available for iOS, the authors collected age and location data for Swiss German speakers and also collected their use of different variables. These data were compared to a 70 -year-old dialectological survey of Swiss German to investigate language change.

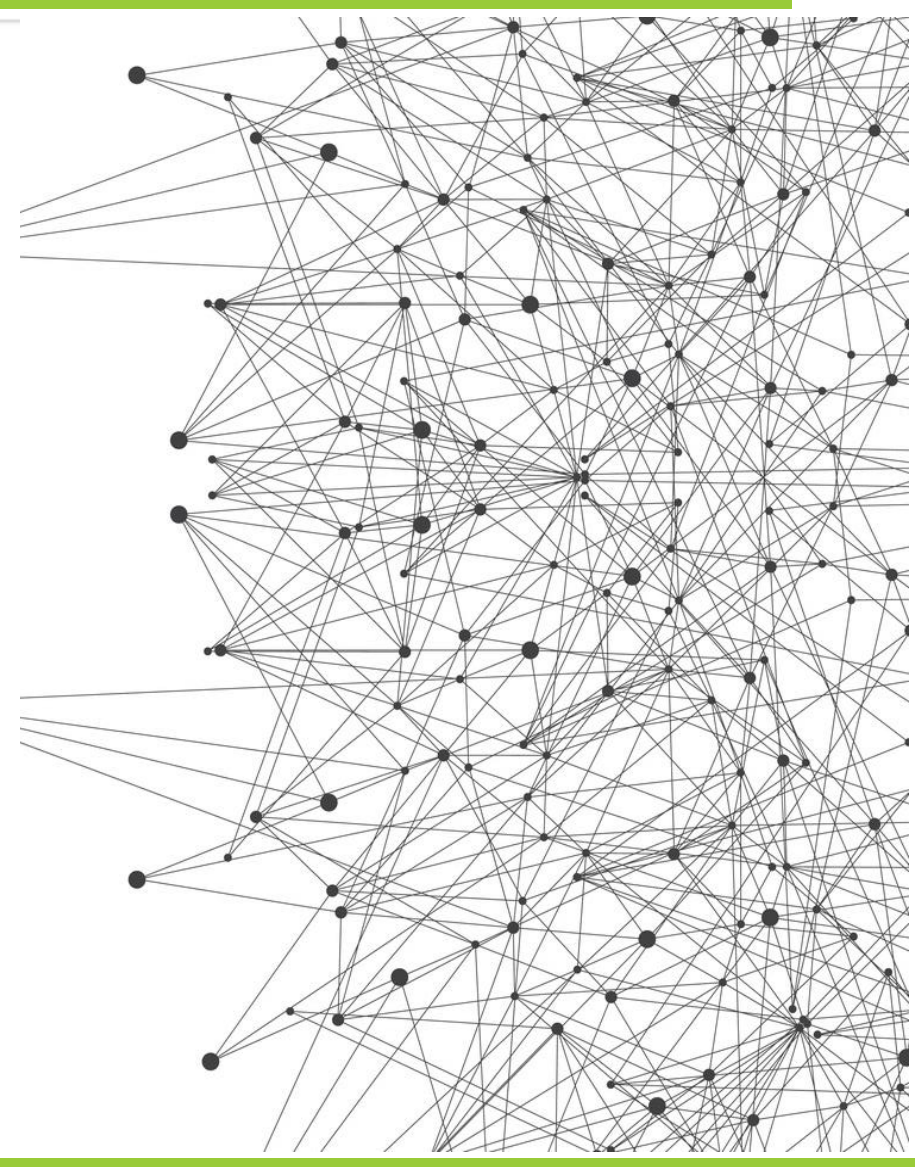

scienceOPEN.com 


\section{Versioning on ScienceOpen}

\begin{tabular}{|c|c|c|c|c|c|c|}
\hline $\begin{array}{c}49,932 \\
\text { views }\end{array}$ & 2 & $\begin{array}{c}1 \\
\text { comments }\end{array}$ & 5 & $\begin{array}{c}1 \\
\text { collections }\end{array}$ & $\begin{array}{l}327 \\
\text { shares }\end{array}$ & $\begin{array}{c}25,795 \\
\text { similar }\end{array}$ \\
\hline [Alt=inetric 470 & MOST CITED & Q commant & +1 recommeno & E ADoto- & Asmuge: & ALL SIMILAR \\
\hline
\end{tabular}

\section{Reviews for article Version 2}

Review by John Smith

Review by Alexander Doe

Reviews for article Version 1

Review by Jason Barr

Review by Pahlad Budrakim

Review by Alexander Doe

Similar articles

25,795

Introducing a teaching module to impart communication skills in the learning anaesthesiologists

Authors: Vaijayanti Nitin Gadre, Kalpana Kelkar, Vidya Kelkar ...

Soft tissue profile in Anatolian Turkish adults: Part II. Comparison of different soft tissue analyses in the evaluation of beauty. Authors: Cem M Caniklioglu, E Erbay

\section{REVEW}

Review of 'Student evaluations of teaching (mostly) do not measure teaching effectiveness'

Author: Jason Barr

Publication date: 07 January 2016

DOl: 10.14293/S2199-1006.1.SOR-EDU.AETBZC.V1

Keywords: Assessment, Evaluation \& Research methods, Labor law, Nonparametric Statistics.

Disparate Impact, Gender Bias, Permutation Tests

\begin{tabular}{|c|c|c|}
\hline \# Add to collection - & E Remove from collection $\mathbf{v}$ & Export as citation - \\
\hline
\end{tabular}

A This review is for a previous version of this article (Version 1). The most recent version is Version 2.

The Boring et al study falls short of other studies investigating gender and student ratings.





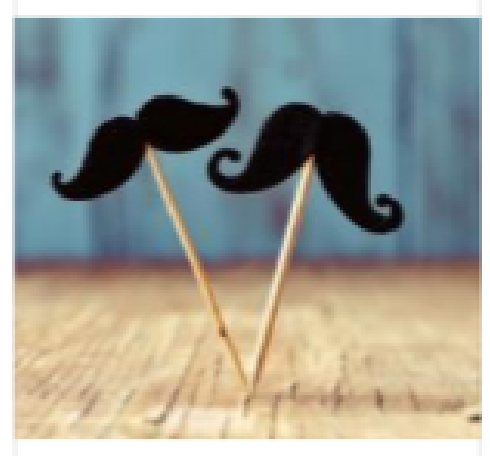


Article: Crossref DOI (with version)

Author: ORCID ID

License: Creative Commons,

Machine-Readable

Funding body/Grant \#: FundRef

Affiliation: Ringgold, GRID

Data: DOI Figshare, Zenodo,

Dryad

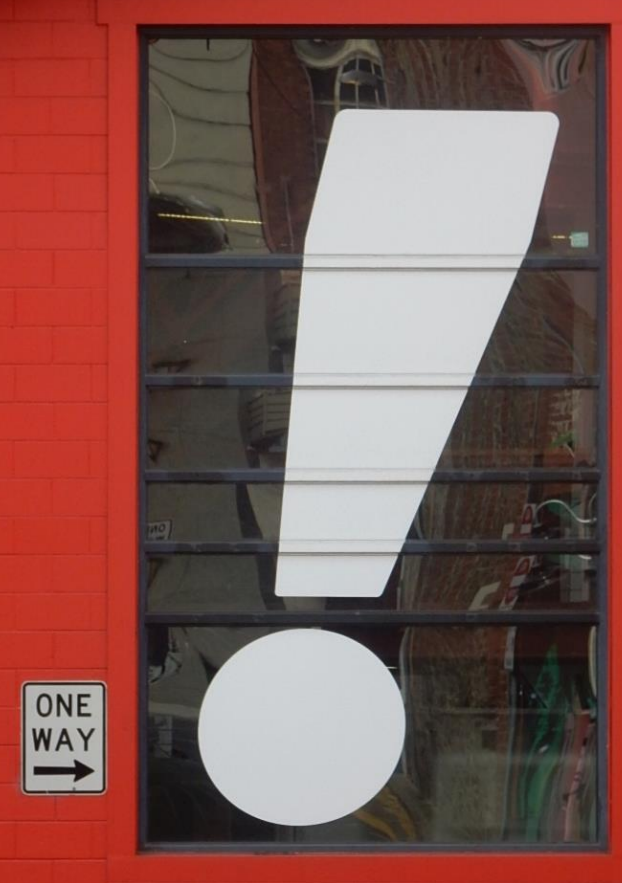


Discovery depends on machine-readable metadata mit persistent identifiers.

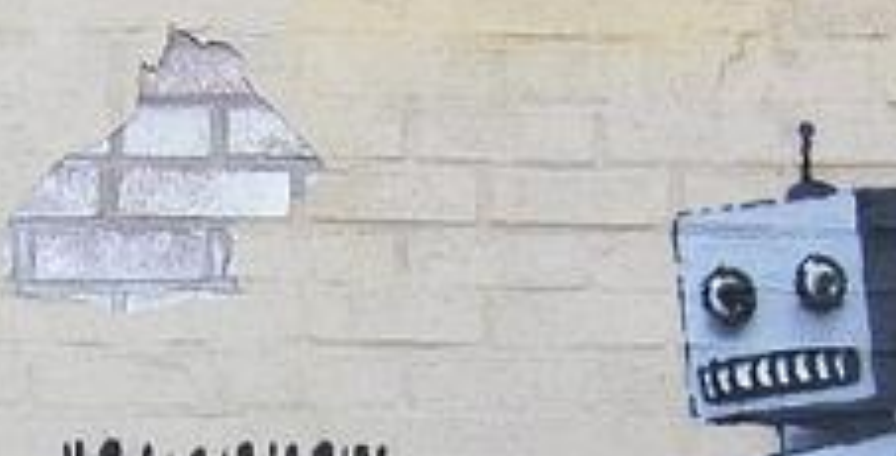

Scott Lynch, Bankey, Flickr_CC BY

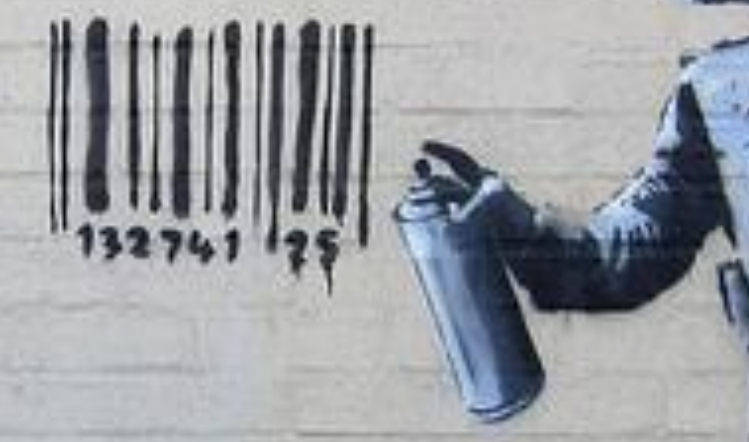


As an aggregator of information,

ScienceOpen will continue to open up,

share, add to and explore the context

of scholarly research in support of open

knowledge goals. Join us!

Contact: Stephanie.Dawson@ScienceOpen.com

Twitter:@Science_Open,@SDawsonBerlin

Facebook: www.facebook.com/ScienceOpen

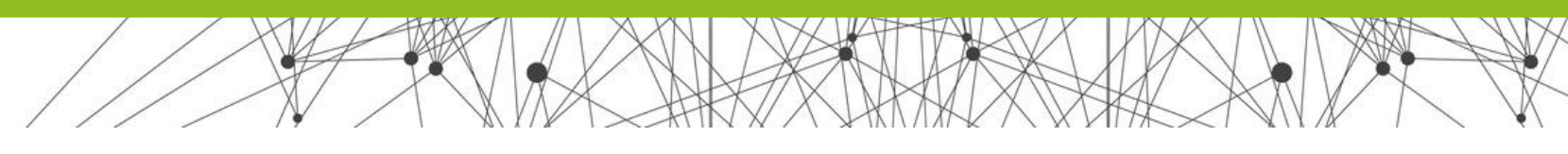


Hindawi

\section{Research Communication: Open Science \& the perverse evaluation cycle}

Catriona J. MacCallum Director of Open Science Hindawi 


\section{Hindawi}

$\checkmark$ Free access - no charge to

\section{Open Access since 2007}

$\sim 18,000$ peer-reviewed articles a year

Science, Technology \& Medicine

A founding member of OASPA access

$\checkmark$ No embargos - immediately

available

$\checkmark$ Reuse - Creative Commons

Attribution License (CC BY) - use

with proper attribution 


\section{Transitioning Subscription Journals: The} Hindawi-Wiley OA Partnership Pilot

8 Richard Bennett () November 17th, 2016

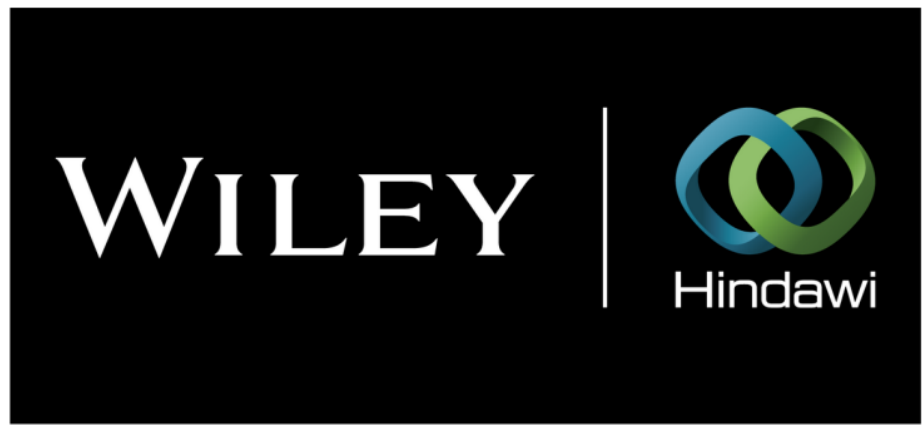

\section{$y$ f $G+$ in $⿴$}

The scholarly journals market has undergone huge transformations in recent years; print subscriptions gave way to electronic distribution, the big deal (for better or worse) came to be the dominant business model used to purchase journals, and open access moved from a small radical movement to become a core part of a scholarly publishers journal strategy.

November 2016
Hindawi signs publishing partnership agreement with AAAS

8 Richard Bennett (ㄷ) September 11th, 2017
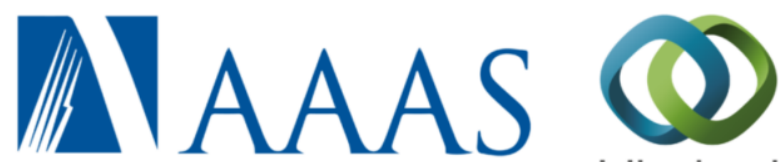

Hindawi

\section{Df $\mathrm{G}$ in}

Hindawi today announced the signing of a publishing partnership agreement with the American Association for the Advancement of Science (AAAS). Hindawi will support AAAS by providing post-acceptance publishing services for AAAS's new Science Partner Journal publishing program. AAAS anticipates its first partner journal will launch in early 2018 . 


\section{Open Science?}

Hindawi

\section{Jeff Rouder}

@JeffRouder

What is Open Science? It is endeavoring to preserve the rights of others to reach independent conclusions about your data and work.

8:47 PM - 5 Dec 2017

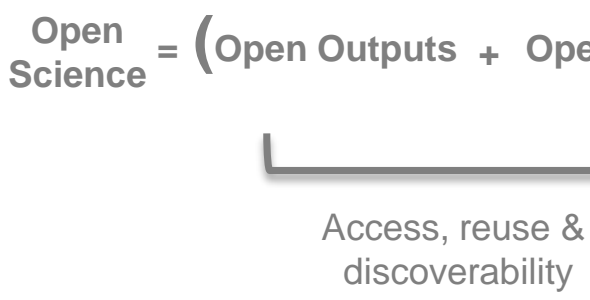$$
\text { X Culture }
$$$$
\text { (change) }
$$
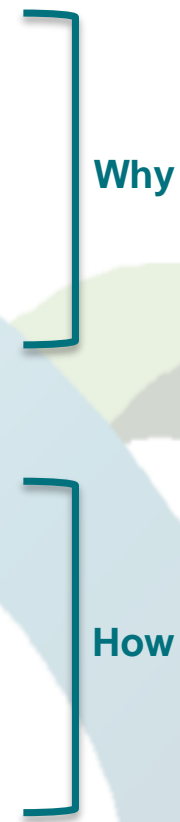


\section{Open Science}

"Open science is about the way researchers work, collaborate, interact, share resources and disseminate results.

....will bring huge benefits for science itself, as well as for its connection with society. " 
"Current incentive structures in science, combined with existing conventions such as a significance level of $5 \%$, encourage rational scientists to adopt a research strategy that is to the detriment of the advancement of scientific knowledge." 


\section{Retraction trends}

Hindawi

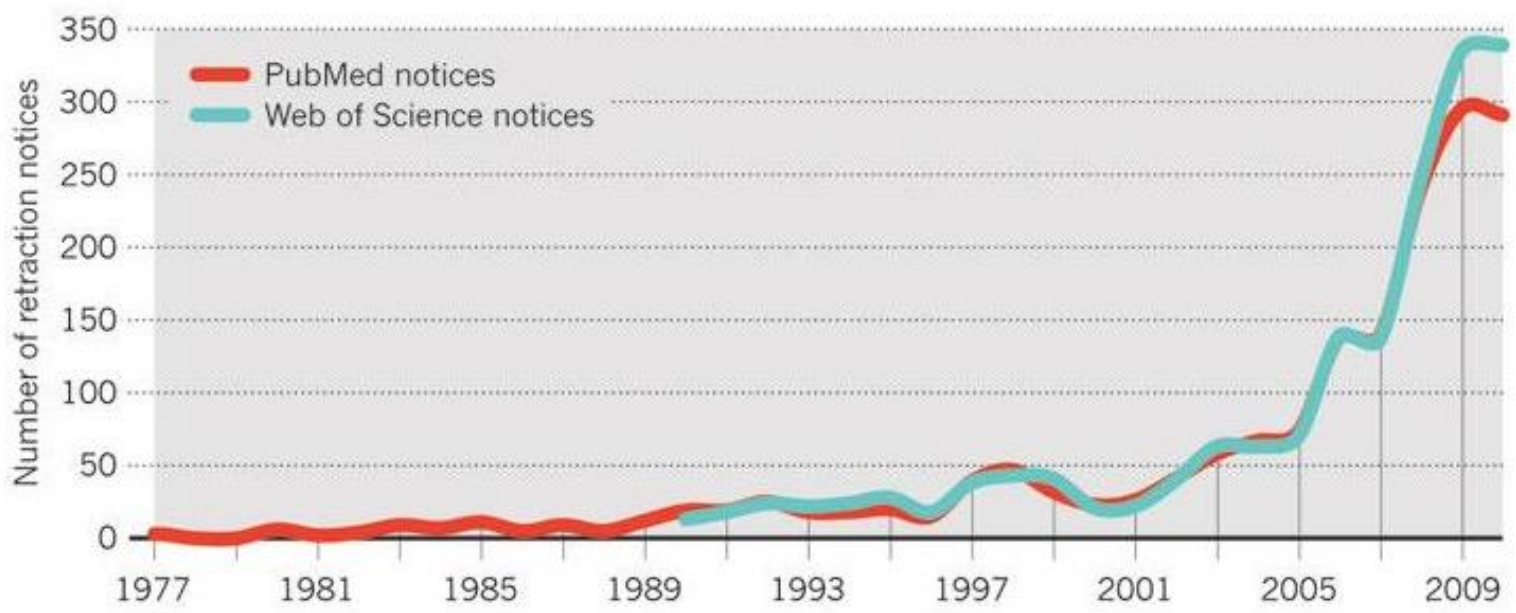

In same period, volume of papers increased by $44 \%$ 


\section{Hindawi}

\section{Is science (communication) trustworthy?}

Science

Communication

- Poorly Designed studies

- small sample sizes, lack of randomisation, blinding and controls

- 'p-hacking' (selective analyses) widespread ${ }^{1}$

- Poorly reported methods \& results ${ }^{2}$

- Negative/inconclusive results are not published

- Data not available to scrutinise/replicate
${ }^{1}$ Head ML, Holman L, Lanfear R, Kahn AT, Jennions MD (2015) The Extent and Consequences of P-Hacking in Science. PLoS Biol 13(3): e1002106.

doi:10.1371/journal.pbio.1002106

2Landis SC, et al. (2012) A call for transparent reporting to optimize the predictive value of preclinical research. Nature 490(7419): 187-191. 


\section{Does prestige ensure 'quality'?}

- Higher ranked journals have more papers retracted ${ }^{1}$

- Papers in higher ranked journals are more likely to report either no or inappropriate statistics ${ }^{2,3}$

- Papers from highly ranked institutions have poorer reporting standards ${ }^{3}$

${ }^{1}$ Fang, Ferric C., and Arturo Casadevall. "Retracted Science and the Retraction Index." Infection and Immunity 79, no. 10 (October 1, 2011): 3855-59. doi:10.1128/IAI.05661-11.

${ }^{2}$ Tressoldi PE, Giofre D, Sella F, Cumming G. High impact = high statistical standards? Not necessarily so. PLOS ONE 2013; 8(2):e56180. doi: 10.1371/journal.pone.0056180 PMID: 23418533

${ }^{3}$ Macleod MR, et al. (2015) Risk of Bias in Reports of In Vivo Research: A Focus for Improvement. PLOS Biol 13(10): e1002273. doi:10.1371/journal.pbio.1002273 


\section{Incentives drive culture}

Hindawi

The biggest barrier to data sharing are the perverse incentives in the reward and evaluation systems that make authors reluctant to share

- The primacy of publications and the journal as a proxy of quality with which to award grants and assign tenure (the impact factor...)

- Financial bonuses

- Lack of reward for data and other outputs

- Lack of transparency \& poor reporting

- Publication bias 
"As competition for jobs and promotions increases, the inflated value given to publishing in a small number of so-called "high impact" journals has put pressure on authors to rush into print, cut corners, exaggerate their findings, and overstate the significance of their work.

Such publication practices, abetted by the hypercompetitive grant system and job market, are changing the atmosphere in many laboratories in disturbing ways."

Rescuing US biomedical research from its systemic flaws Bruce Alberts, Marc W. Kirschner, Shirley Tilghman, and Harold Varmus PNAS | April 22, 2014 | vol. 111 | no. 16 | 5773-5777 doi: 10.1073/pnas. 1404402111 


\section{Bullied into bad science}

\section{The letter}

ECRs: sign the letter

Non-ECRs: support the campaign

Press coverage

Contacts

Interact

Additional actions

The Bullied Into Bad Science campaign is an initiative by early career researchers (ECRs) for early career researchers who aim for a fairer, more open and ethical research and publication environment. (University of Cambridge)

http://bulliedintobadscience.org/
We are postdocs and a reader in the humanities and sciences at the University of Cambridge. We are concerned about the desperate need for publishing reform to increase transparency, reproducibility, timeliness, and academic rigour of the production and dissemination of scholarly outputs (see Young et al. 2016, Smaldino \& McElreath 2016).

We have identified actions that institutions and managers can take to better support ECRo (betowv). Thesenactions are crucial for our succesefecause we are eager to publish openly and at places that keep profits inside academia in accordance with many yfodern online publication venues (Logan 2017). However, ECRs are often pressured into publishing against their ethics through threats that we would not get a job/grant unless we publish in particular journals (Carter et al. 2014, Who is going to make change happen?, Kent 2016; usually these journals are order and more familiar, have a print version, a high impact facto and are not $100 \%$ open access). These out of date practices 2nd ideas hindeNECRs rather than help us: evidence showothat publishing open access tesulto in inorecect cltations, media attention, and job/funding opportunities (McKiernan et al. 2016). Open dissemination of all research outputs is also a fundamental principle on which ECRs rely to fight the ongoing reproducibility crisis in science and thus improve the quality of their research.

To support ECRs in this changing publishing landscape, we encourage funders, universities, departments, and politicians to 
Clinical trial registration: Looking back and moving ahead

(Published mid 2007)

New Eng.J. Med. 45 (53.298)

Lancet 24 (38.278)

J.Am.Med.Assoc. 21 (30.026)

Annals Int. Med. II (16.733)

Brit.Med.J. 7 (14.093)

Can. Med.Assoc.J. 4 (8.217)

Med.J.Aust. I (2.813)

Croat. Med.J. 9 (1.796)

Total citations until the end of 2011 (201I Impact Factor)

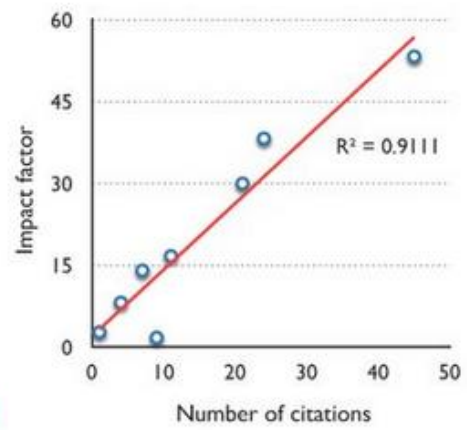




\section{Current culture embeds status quo}

- Researchers gain from publishing in 'designer' journals

- Journals gain financially from their brand/Journal Impact factor

- Institutions gain financially by hiring and firing based on where researchers publish, not on what they publish (or the mission of the University)

- Research assessment by funders often based on very few publications and brand/impact factor (some are changing)

- Entrenched sub-conscious bias 


\section{theguardian}

Higher Education

Network

Occam's corner

\section{0}

\section{Stephen Curry}

Professor of structural biology at Imperial College London

- @Stephen_Curry

\section{It's time for academics to take back} control of research journals

The evolution into a highly-profitable industry was never planned. Academics must make the case for lower-cost journals

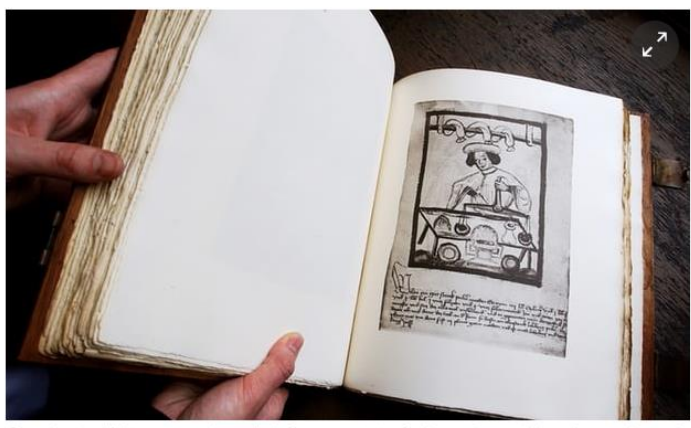

(1) Academic publishing digin

Levene for the Guardian

"Publish or perish" has long been the mantra of academics seeking to make a success of their research career. Reputations are built on the ability to communicate something new to the world. Increasingly, however, they are determined by numbers, not by words, as universities are caught in a tangle of management targets composed of academic journal impact factors, university rankings and scores in the government's research excellence framework.

\section{Untangling academic publishing: a history of nata the relationship between commercial interests, academic prestige and the circulation of research \\ Research output: Book/Report , Other report \\ Overview Citation formats Activities and awards Funded projects}

\section{Standard}

Untangling academic publishing : a history of the relationship between commercial interests, academic prestige and the circulation of research. / Fyfe, Aileen; Coate, Kelly; Curry, Stephen; Lawson, Stuart; Moxham, Noah; Rostvik, Camilla Mork.

St Andrews : University of St Andrews, 2017. 26 p. Research output: Book/Report , Other report

\section{Harvard}

Fyfe, A, Coate, K, Curry, S, Lawson, S, Moxham, N \& Rostvik, CM 2017, Untangling academic publishing: a history of the relationship between commercial interests, academic prestige and the circulation of research. University of St Andrews, St Andrews. DOI: 10.5281 /zenodo. 546100

\section{APA}

Fyfe, A., Coate, K., Curry, S., Lawson, S., Moxham, N., \& Rostvik, C. M. (2017). Untangling academic publishing: a history of the relationship between commercial interests, academic prestige and the circulation of research. St Andrews: University of St Andrews. DOI: 10.5281/zenodo.546100

\section{DO}

10.5281/zenodo.546100

Open Access permissions

Open

Links

Open Access version in St Andrews Research Repository 


\section{SciHub}

Hindawi

(and a disclaimer)

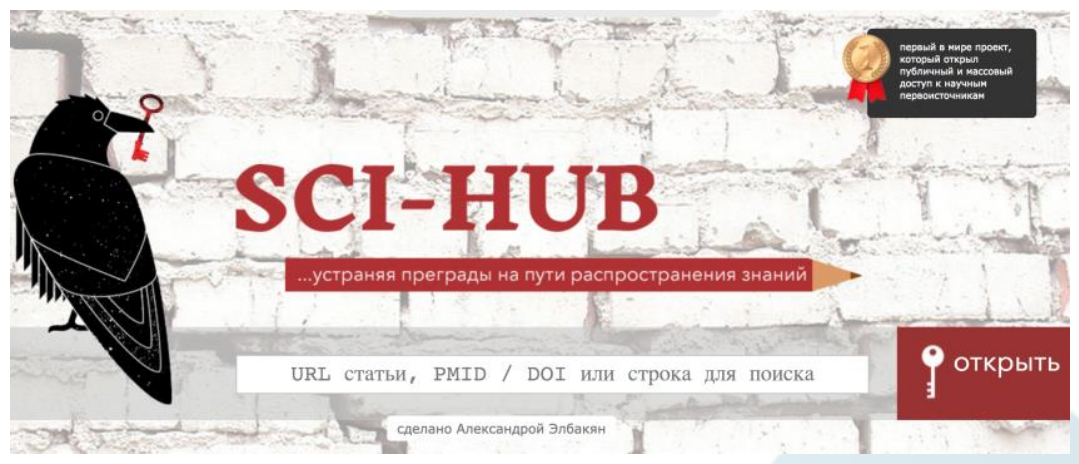

"Readers [audience] should note that, in many jurisdictions, use of Sci-Hub may constitute copyright infringement. Users of Sci-Hub do so at their own risk. This study [and talk...] is not an endorsement of using Sci-Hub, and its authors and publishers accept no responsibility on behalf of readers."

Himmelstein DS, Romero AR, McLaughlin SR, Greshake Tzovaras B, Greene CS. (2017) Sci-Hub provides access to nearly all scholarly literature. PeerJ Preprints 5:e3100v1 https://doi.org/10.7287/peeri.preprints.3100v1 


\section{Publisher as service provider}

- Encourage and facilitate better forms of credit

- ORCID

- $\quad$ CRediT taxonomy

- Data /software citations

- Protocols

- Preprints

- Citation distributions

- Encourage data / software / materials sharing

- Provide high quality metadata

- Reduce friction

- Enable connections and discovery

- $\quad$ Adopt relevant persistent identifiers

- Reduce the burden on researchers

- Reduce the burden for funders and institutions

- Enable a machine readable ecosystem 


\section{Community ownership}

\section{A radically open approach to developing infrastructure for Open Science}

\section{Paul Peters (c) October 23rd, 2017}

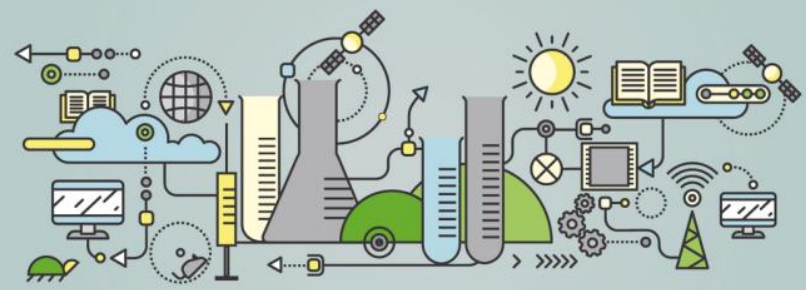

If $\mathrm{G}+$ in $\mathrm{Q}$

Hindawi's CEO, Paul Peters, explains the problems inherent in proprietary solutions for Open Science infrastructure and presents a proposal for how things can be done differently.

Should commercial companies have a role in developing infrastructure for an Open Science future?

most of the data needed to support Open

Science is controlled by commercial companies, both big and small. This growing reliance on a handful of companies to provide proprietary analytics and decision tools for research funders and universities poses serious risks for the future

\section{Open Source}

- prevents monopolistic control

- requires an active community of users and service providers to develop and maintain infrastructure

\section{Open Data}

- metadata about the research process itself, such as funding data, publication and citation data, and "altmetrics" data

\section{Open Integrations}

- $\quad$ standard metadata formats and open APIs

\section{Open Contracts}

- completely open (public) and no lock-in (e.g. Non-Disclosure Agreements, multi-year contract terms, and privately negotiated prices) 


\section{AUCLL}

\section{¿UCLPRESS}

Open Access

Megajournal Project

Ian Caswell

Journals Manager, UCL Press

i.caswell@ucl.ac.uk

(c) (i) Slides made available under

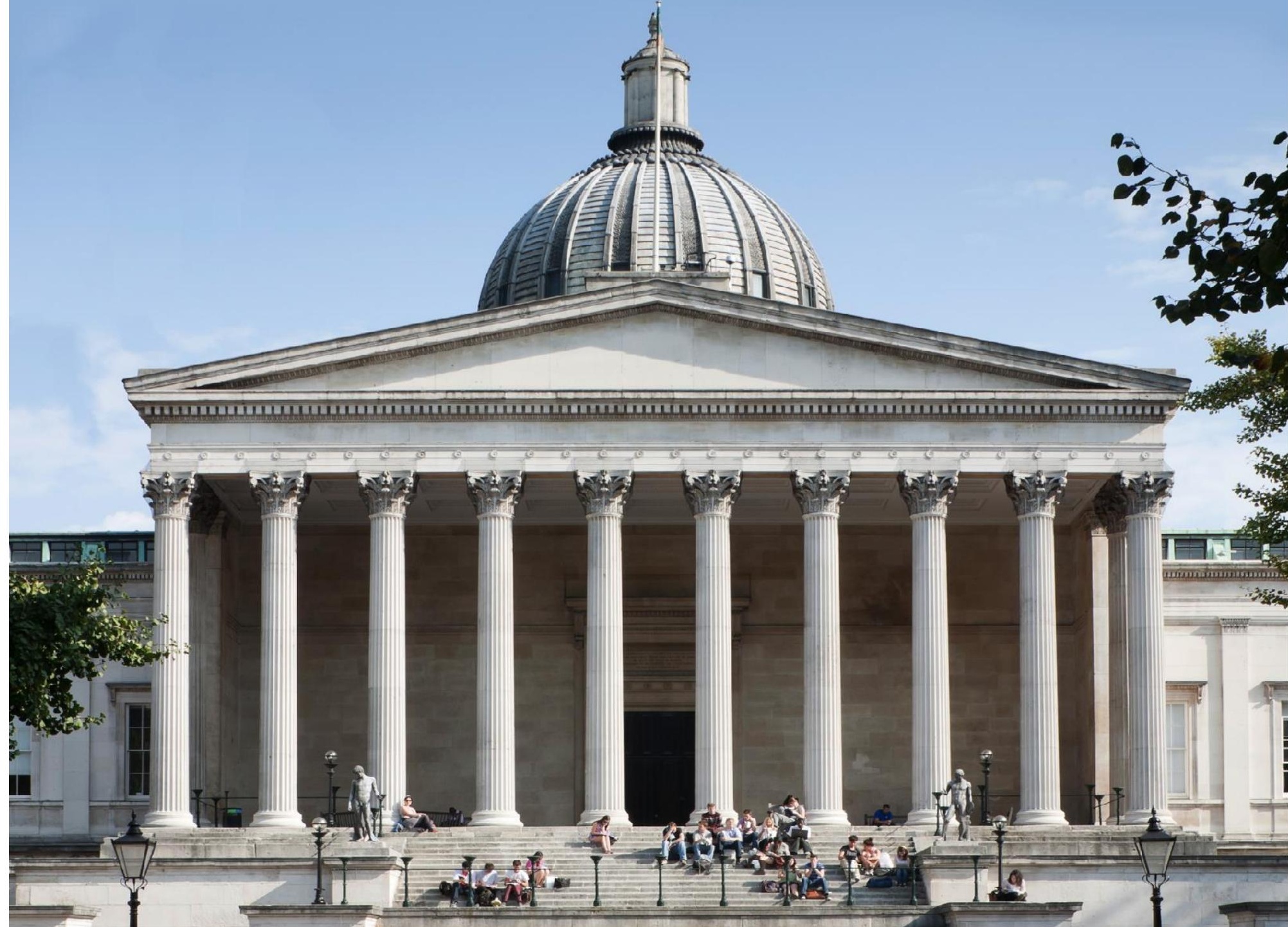


'Scholarly outputs are typically subjected to a publications process that limits their widespread dissemination. UCL is committed to being a force for good and enlightenment in the world. This includes ensuring that the products of its research are made as widely available as possible.'

\section{UCL Press mission}

Professor David Price, Vice Provost (Research), UCL
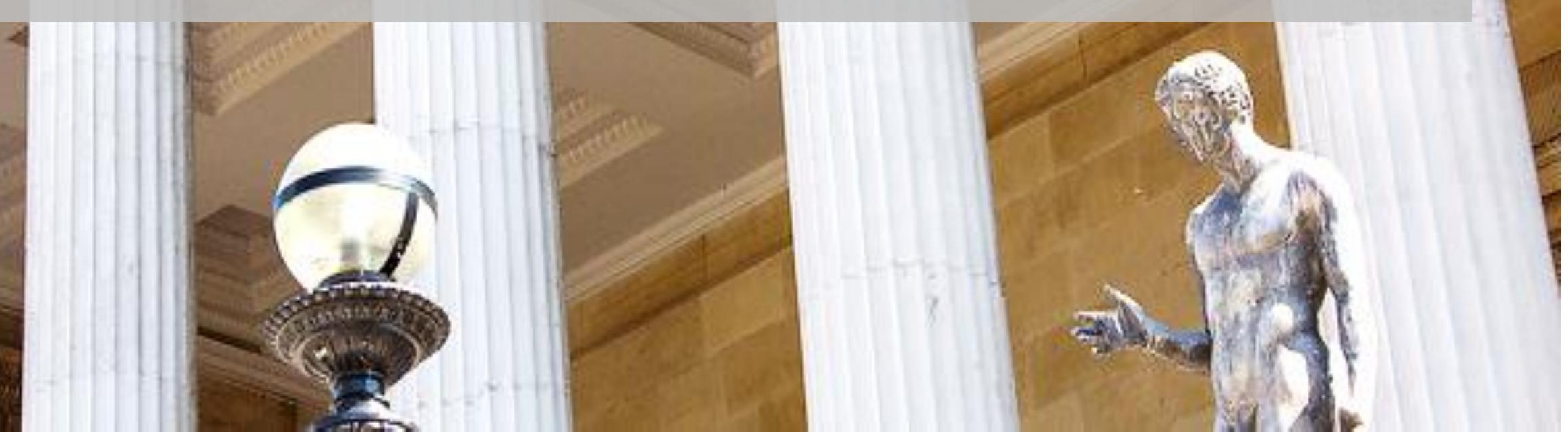


\section{About UCL Press}

56 fully peer reviewed books

Innovative publication in all subject areas

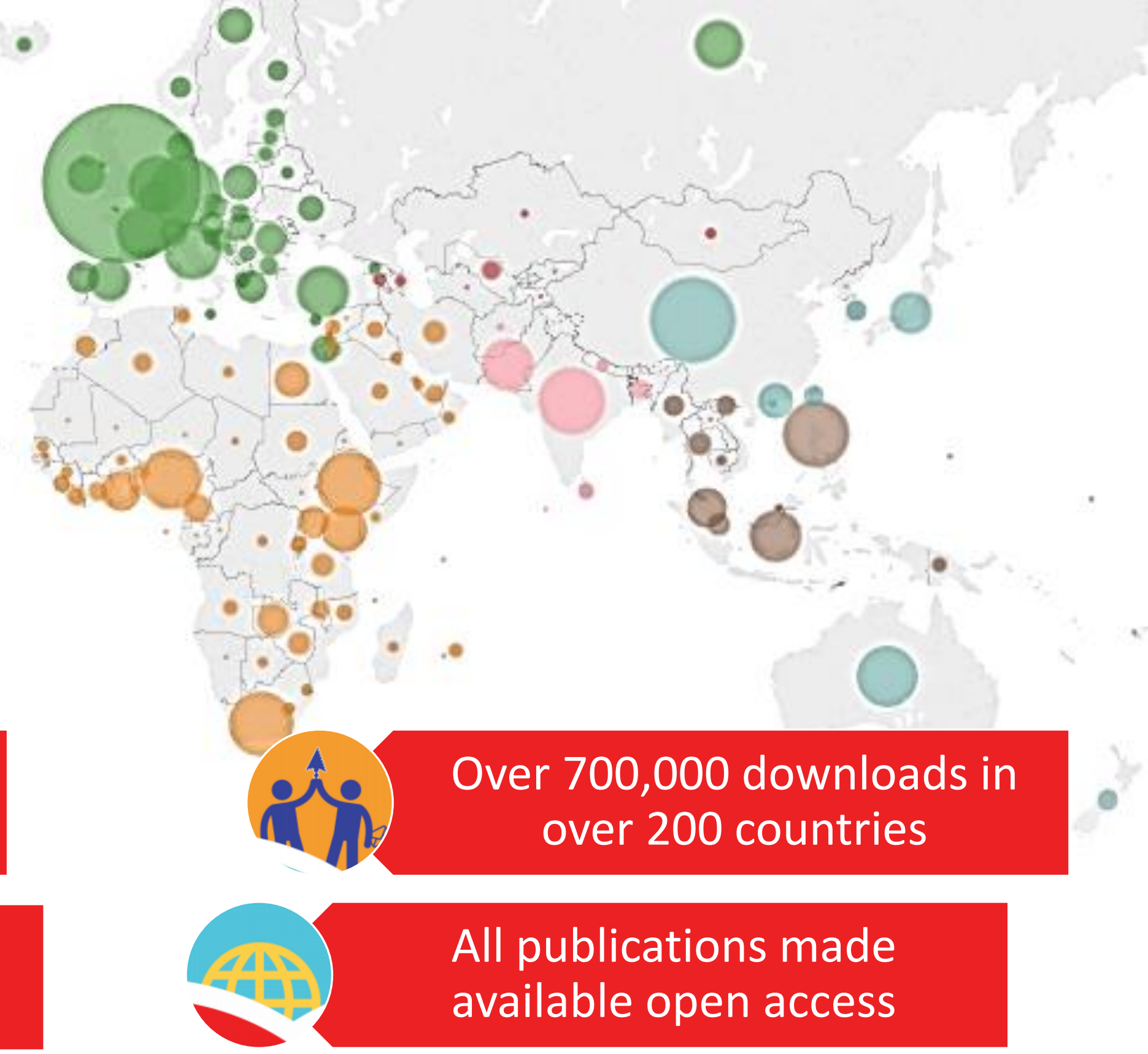

${ }^{\star U}$ UCLPRESS 


\section{Our Aims for a UCL Press Megajournal}

\section{Rapid publication}

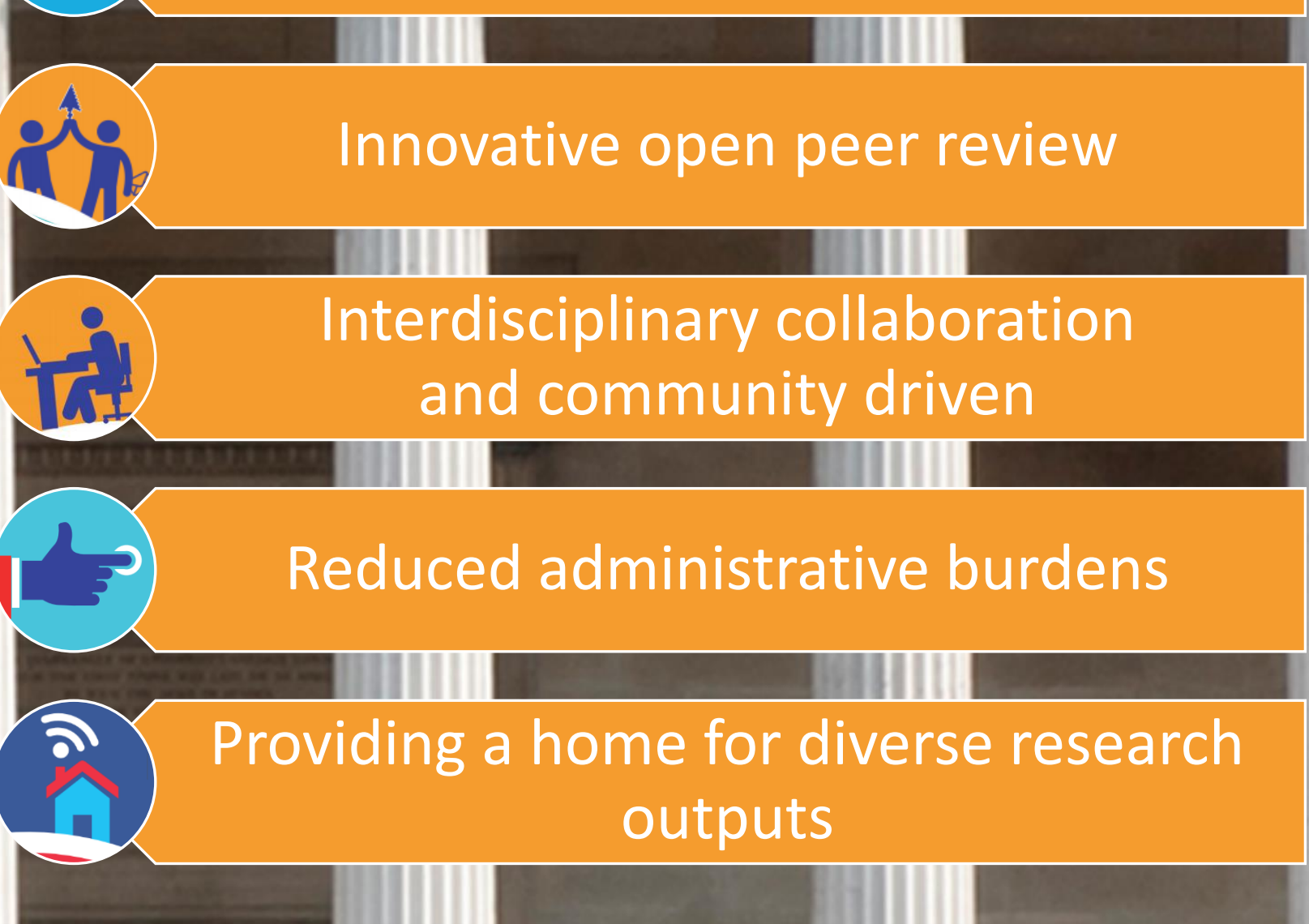




\section{Advantages of a new model at UCL Press}

Open, transparent, and accountable | Diverse research outputs | Universal and unrestricted dissemination

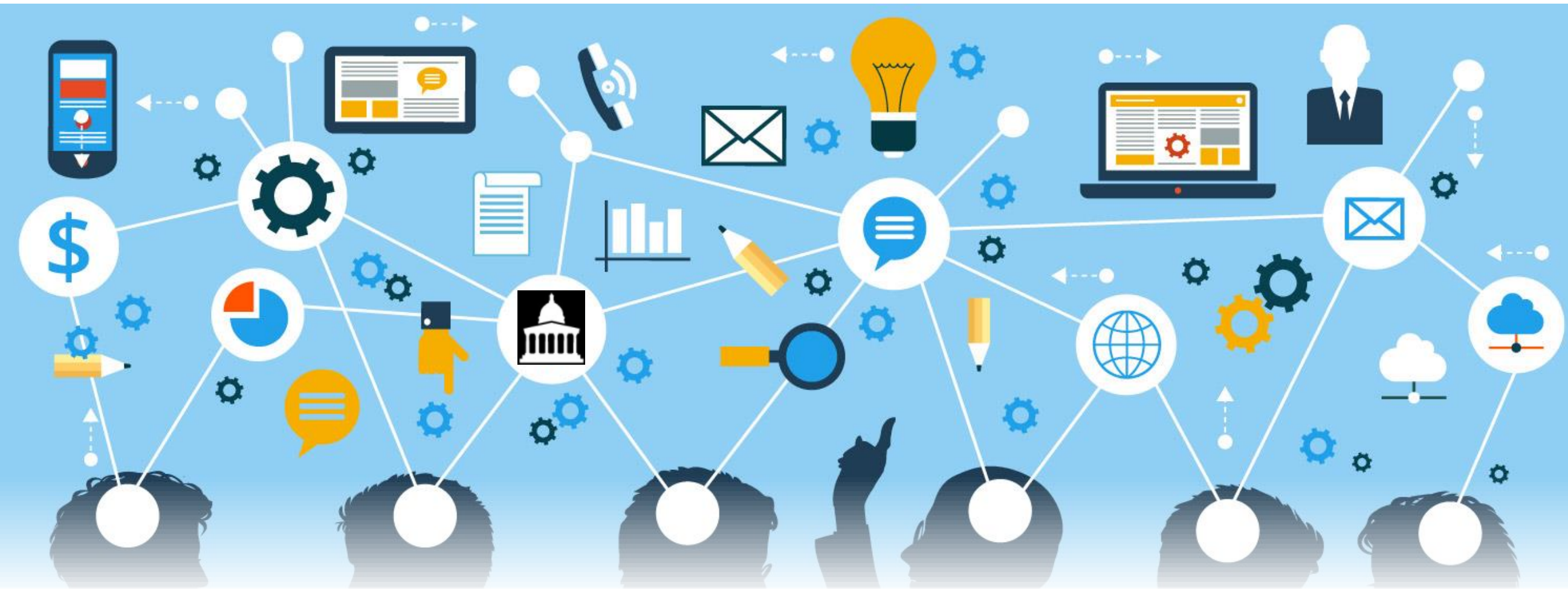


Next steps
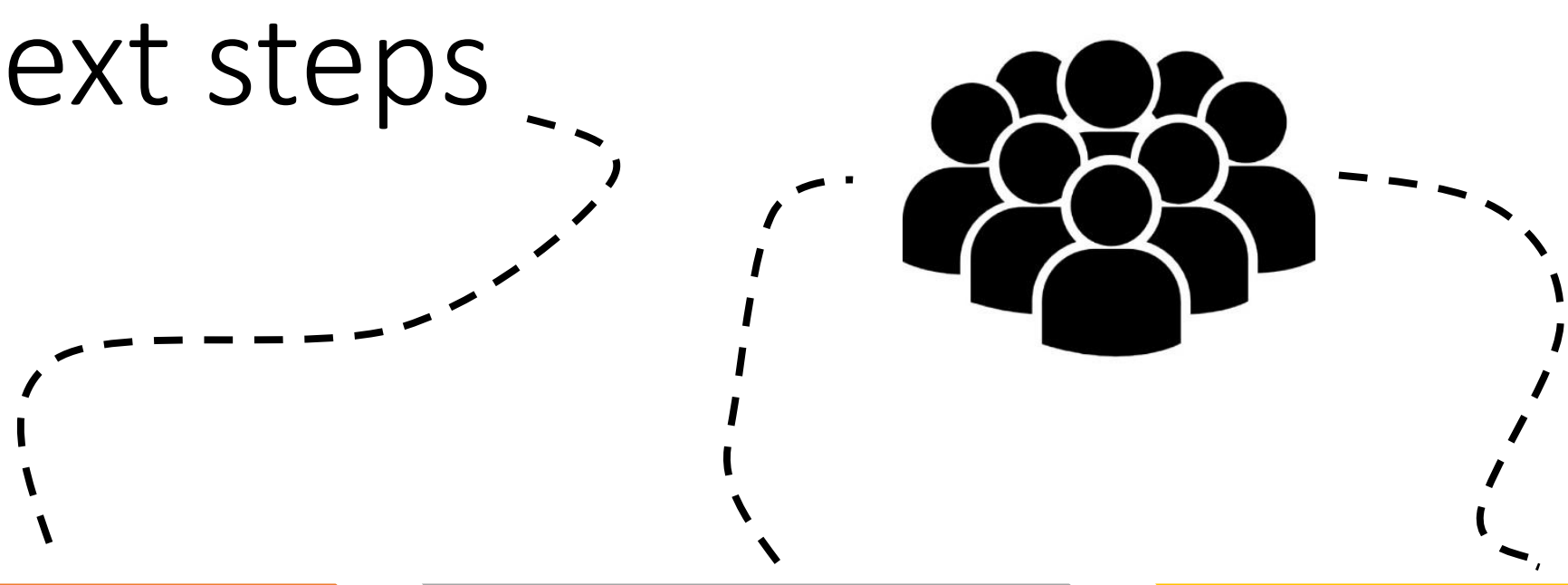

Pilot
Editorial board
Open peer review

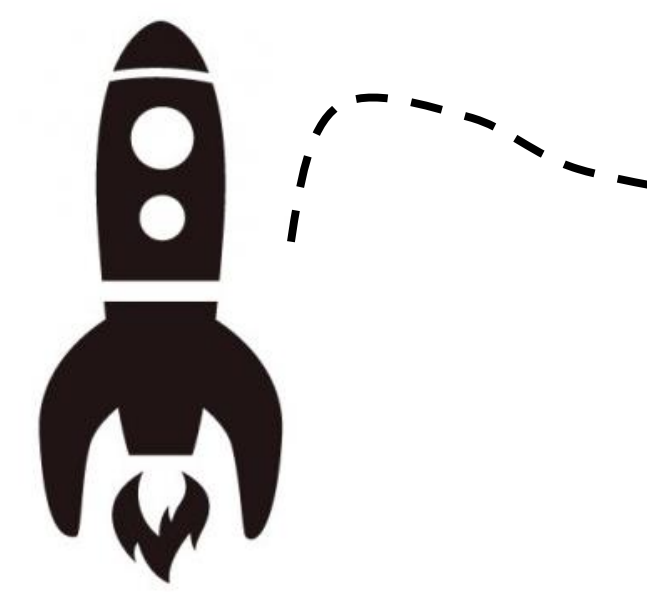

Launch and further development

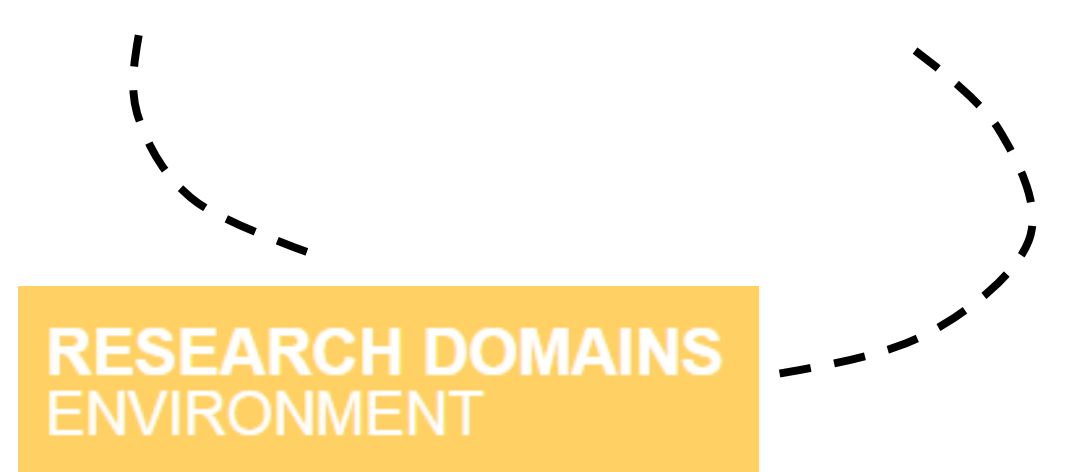




\section{Our platform}

\section{ScienceOPEN.com research+publishing network}

See the UCL Press journals at https://www.scienceopen.com/collection/UCLPress 
Stay in touch and get involved, contact:

Ian Caswell

Journals Manager, UCL Press

i.caswell@ucl.ac.uk

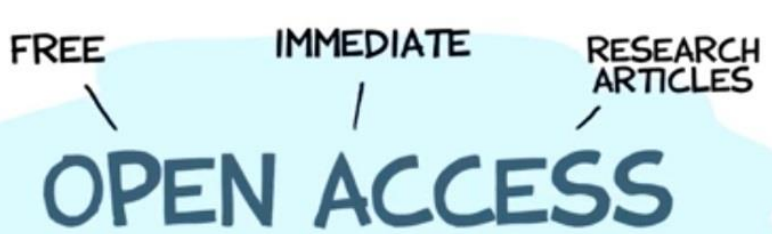

Panel Q\&A

\section{OPEN ACCESS}


Nick Shockey and Jonathan Eisen

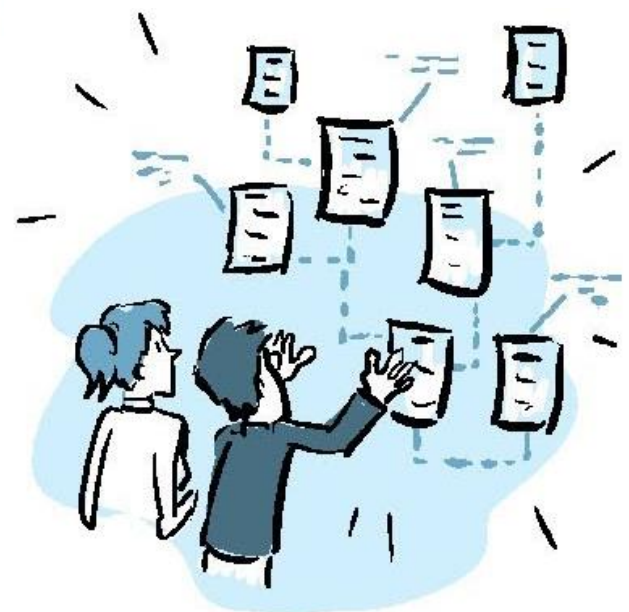

so people can do interesting things in new ways with the materials.
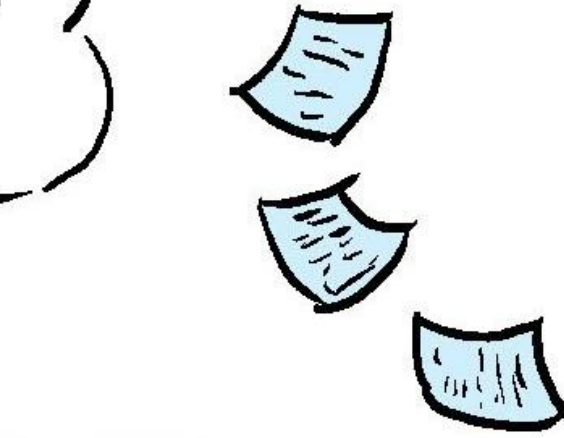

Chair: Prof David Price, UCL Vice-Provost (Research)

Dr Paul Ayris, Pro-Vice-Provost (UCL Library Services)

Robert Kiley, Wellcome Trust

Stephanie Dawson,

ScienceOpen

Catriona MacCallum, Hindawi

Ian Caswell, UCL Press 